\title{
Targeting CAMP/PKA pathway for glycemic control and type 2 diabetes therapy
}

\author{
Haihua Yang' and Linghai Yang ${ }^{2}$ \\ 'Division of Endocrinology, Zhengzhou Children's Hospital, Zhengzhou, Henan, China \\ 2Department of Pharmacology, University of Washington, Seattle, Washington, USA
}

Correspondence should be addressed to $\mathrm{H}$ Yang or L Yang Email yhhua415@163.com or linghai@uw.edu

\begin{abstract}
In mammals, cyclic adenosine monophosphate (CAMP) is an intracellular second messenger that is usually elicited by binding of hormones and neurotransmitters to $G$ protein-coupled receptors (GPCRs). cAMP exerts many of its physiological effects by activating CAMPdependent protein kinase (PKA), which in turn phosphorylates and regulates the functions of downstream protein targets including ion channels, enzymes, and transcription factors. CAMP/PKA signaling pathway regulates glucose homeostasis at multiple levels including insulin and glucagon secretion, glucose uptake, glycogen synthesis and breakdown, gluconeogenesis, and neural control of glucose homeostasis. This review summarizes recent genetic and pharmacological studies concerning the regulation of glucose homeostasis by CAMP/PKA in pancreas, liver, skeletal muscle, adipose tissues, and brain. We also discuss the strategies for targeting CAMP/PKA pathway for research and potential therapeutic treatment of type 2 diabetes mellitus (T2D).
\end{abstract}
Key Words
- PKA
- diabetes
- glucose
- insulin
- glucagon

\section{cAMP/PKA pathway}

cAMP was initially discovered as an intracellular mediator of the glycogenolytic effect of glucagon and epinephrine in the liver (Berthet et al. 1957). It was later revealed in skeletal muscle that the glycogenolytic effect of cAMP depends on a cascade of protein phosphorylation: cAMP/ PKA-phosphorylase kinase-glycogen phosphorylaseglycogen degradation, which was a breakthrough discovery in biochemistry showing that protein phosphorylation is a regulatory mechanism for enzyme activity. The 1992 Nobel Prize in Physiology or Medicine was awarded to Edwin Krebs and Edmond Fischer for their discovery of this phosphorylation cascade. The major receptors for cAMP in mammals are PKA regulatory $(\mathrm{R})$ subunits and exchange proteins directly activated by cAMP (Epac). The role of Epac in the regulation of metabolism has been recently reviewed (Almahariq et al. 2014). The physiological role of PKA in glucose metabolism is increasingly appreciated with the availability of genetically modified mice and pharmacological evidence.

In cells, cAMP is synthesized from adenosine triphosphate (ATP) catalyzed by adenylyl cyclase (AC), which is activated by stimulatory $G \alpha$ protein (Gs $\alpha$ ) following the activation of Gs protein-coupled receptors (Fig. 1). The termination of cAMP signaling is mediated by the conversion of cAMP to AMP by phosphodiesterases (PDEs) (Furman et al. 2010). PKA is a serine/threonine kinase and the holoenzyme is inactive and formed by a dimer of two regulatory (R) subunits that each binds a catalytic (C) subunit (Krebs \& Beavo 1979). Each R subunit contains two cAMP binding sites, and cAMP binding leads to conformational changes in the $\mathrm{R}$ subunits and release of the active $\mathrm{C}$ subunits. Four types of $\mathrm{R}$ subunits 


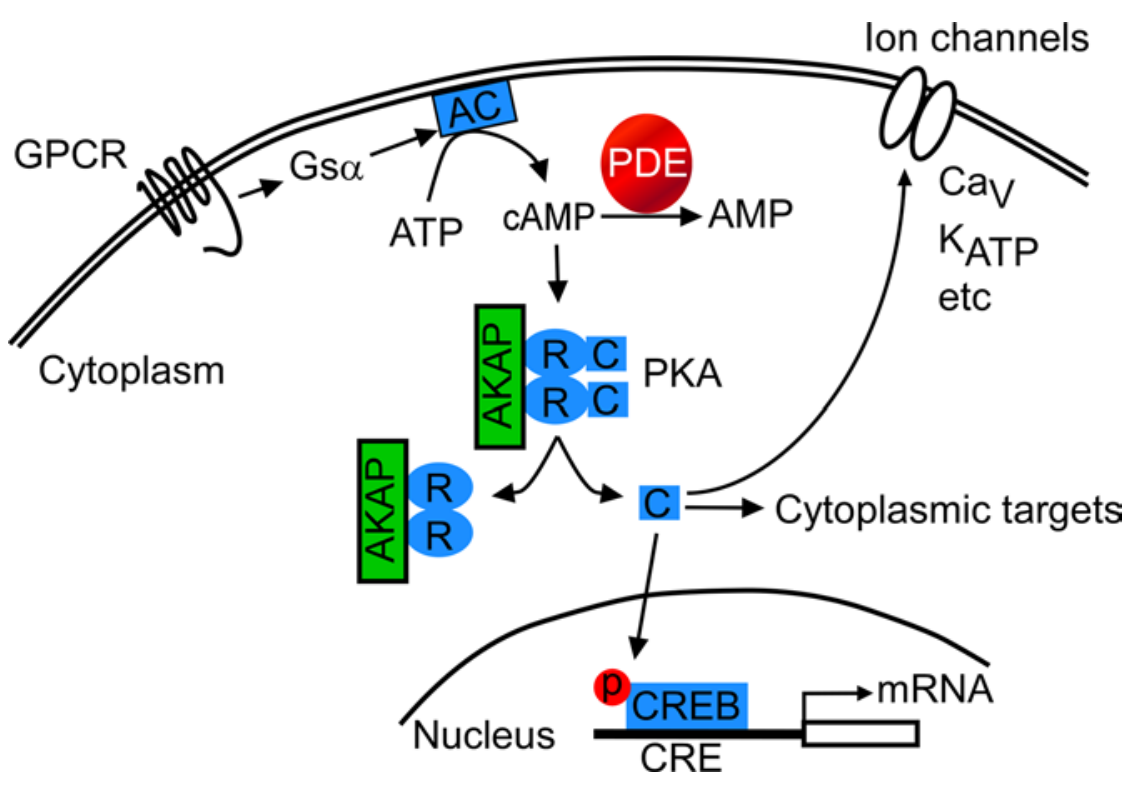

Figure 1

CAMP/PKA signaling pathway in mammalian cells. The activation of CAMP/PKA signaling starts from ligand-dependent activation of the $G$ proteincoupled receptors (GPCRs) and is followed by Gs $\alpha$ activation, adenylyl cyclase (AC) activation, and cAMP generation. CAMP activates PKA by binding to PKA regulatory subunits (RIs or Rlls). The PKA catalytic subunits $(C)$ are then released from the PKA tetramer to phosphorylate targets in the cytoplasm, in the plasma membrane $\left(\mathrm{Ca}_{\mathrm{V}}, \mathrm{K}_{\mathrm{ATP}}\right.$ etc.), and in the nucleus (CREB). The subcellular localization of PKA is dependent on binding of $R$ subunits to different A-kinase anchoring proteins (AKAPs). The termination of cAMP signaling is dependent on phosphodiesterases (PDEs)-mediated degradation of CAMP to AMP. A full colour version of this figure is available at http://dx.doi.org/10.1530/JME-15-0316.

(RI $\alpha$, RI $\beta$, RII $\alpha$, and RII $\beta$ ) and two types of $\mathrm{C}$ subunits (C $\alpha$ and $C \beta$ ) have been identified in mice to be encoded by different genes. In human, a third $\mathrm{C}$ subunit $(\mathrm{C} \gamma)$ gene has been identified specifically in testes and postulated to be a retroposon of the C $\alpha$ gene (Beebe et al. 1990, Reinton et al. 1998). In general, the $\alpha$ isoforms of RI, RII, and C subunits are expressed in all tissues, whereas $\beta$ isoforms show more restricted expression. Type I PKA holoenzymes contain homodimers of RI $\alpha$ or RI $\beta$ subunits and are activated at a lower cAMP level compared with type II holoenzymes containing homodimers of RII $\alpha$ or RII $\beta$ subunits. The subcellular localization of PKA is dependent on the binding of $\mathrm{R}$ subunits to A kinase anchoring proteins (AKAPs), which generally show higher affinity for type II holoenzymes (Tasken \& Aandahl 2004). Binding to AKAPs is essential for the spatial and temporal regulation of cAMP/PKA signaling (Fig. 1) (Smith et al. 2006, Pidoux \& Tasken 2010). Mice with global or conditional mutants of $\mathrm{R}$ subunits, $\mathrm{C}$ subunits, or AKAPs have been generated (Kirschner et al. 2009) and greatly enhanced our understanding of the role of cAMP/PKA in different physiological and pathological processes, such as neural synaptic plasticity (Rosenmund et al. 1994), cardiac hypertrophy (Antos et al. 2001, Enns et al. 2010), tumor progression (Kirschner et al. 2000), and glucose homeostasis (Niswender et al. 2005, Willis et al. 2011).

Blood glucose is regulated by coordinated actions of different tissues, especially the pancreatic islet, liver, skeletal muscle, fat, and the brain (Fig. 2). This review discusses how cAMP/PKA signaling in each of these tissues affects glucose homeostasis and potential strategies targeting this pathway for glycemic control.

\section{CAMP/PKA in pancreatic islets}

$\beta$ cell

A hallmark of T2D is an early defect in glucose-stimulated insulin secretion from pancreatic $\beta$ cells (Nolan et al. 2011). Following a meal, glucose levels in the circulation increase, leading to increased uptake of glucose into $\beta$ cells via the glucose transporter GLUT2. Increased intracellular glucose then leads to production of ATP and inactivation of the ATP-sensitive potassium channel $\left(\mathrm{K}_{\text {ATP }}\right)$ and depolarization of the cell. Cell depolarization activates voltage-gated calcium channel (Cav) on the plasma membrane and calcium influx into $\beta$ cells. Accumulation of $\mathrm{Ca}^{2+}$ in the cell then promotes insulin secretion via exocytosis. Subsequently, insulin circulates and acts on a variety of tissues, mainly fat, muscle, and liver, to increase glucose uptake and inhibit glucose production. This process is essential for postprandial glycemic control.

Although glucose is the primary regulator for insulin secretion, many hormones and neurotransmitters such as glucagon, glucagon-like peptide 1 (GLP1), epinephrine, and norepinephrine can either enhance or suppress insulin secretion through GPCRs on $\beta$ cells (Ahren 2009). cAMP/PKA pathway acts downstream of the GPCRs and regulates the activities of key molecules involved in insulin secretion, including GLUT2, $\mathrm{K}_{\mathrm{ATP}}$, and Cav (Fig. 3A). It has been shown that GLUT2 is phosphorylated at multiple sites in the carboxyl-terminal domain by PKA following either forskolin or GLP1 stimulation of $\beta$ cells (Thorens et al. 1996). PKA-dependent phosphorylation suppresses the catalytic activity of GLUT2 and reduces glucose uptake into $\beta$ cells (Thorens et al. 1996). However,

Published by Bioscientifica Ltd. 


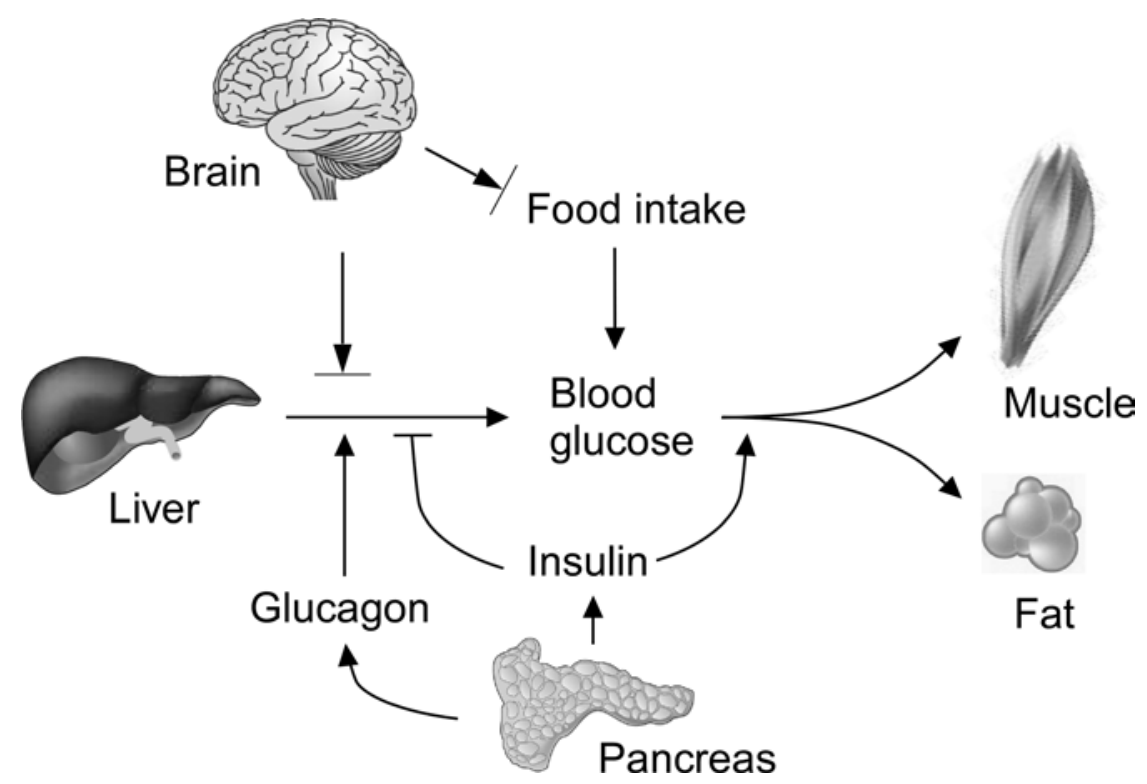

Figure 2

Glucose homeostasis is regulated by the coordinated actions of various organs. Glucose inputs from food absorption and hepatic release can be either inhibited or increased by neural signals from the brain. Hepatic glucose production (HGP) is increased by glucagon during fasting and inhibited by insulin after food absorption. Insulin also lowers blood glucose by stimulating its uptake into various tissues, mainly muscle and fat tissue. Glucose uptake by liver and brain does not require insulin (not shown). The secretions of glucagon and insulin by pancreatic $\alpha$ and $\beta$ cells, respectively, are regulated by glucose and hormones. because activation of PKA potentiates glucose-induced insulin release, these results suggest that phosphorylation of GLUT2 may regulate insulin secretion independent of its transporter activity (Hughes et al. 1993).

$\mathrm{K}_{\text {ATP }}$ channels serve to couple cellular metabolism to electrical excitability in pancreatic $\beta$ cells and are the targets for sulfonylureas, a group of antidiabetic drugs. $\mathrm{K}_{\text {ATP }}$ channels are regulated by receptor-mediated signals that modulate insulin release, including the cAMP/PKA pathway (Beguin et al. 1999, Chen et al. 2013). PKAdependent phosphorylation of $\mathrm{K}_{\text {ATP }}$ channels at S1448 in the SUR1 subunit inactivates the channels in an ADPdependent manner and is required for GLP1 stimulation of insulin secretion (Light et al. 2002). In another scenario, however, leptin-induced PKA activation in $\beta$ cells promotes $K_{\text {ATP }}$ trafficking to the plasma membrane, increases potassium current, and inhibits insulin release (Chen et al. 2013). Thus, under different conditions, cAMP/PKA activation may have either positive or negative effect on insulin release through $\mathrm{K}_{\mathrm{ATP}}$ regulation, although it remains unknown if leptin treatment also leads to increased phosphorylation of $\mathrm{K}_{\mathrm{ATP}}$ channels by PKA. This discrepancy can be due to that GLP1 and leptin activate distinct PKA pools that have different subcellular localizations and downstream targets within $\beta$ cells.

Multiple types of Cav channels have been identified in pancreatic $\beta$ cells and play essential roles in insulin secretion as well as $\beta$ cell development, survival, and growth (Yang \& Berggren 2006). L-type Cav1.2 and Cav1.3 are the major mediators of Cav current in $\beta$ cell from many species tested (Sinnegger-Brauns et al. 2004,
Yang \& Berggren 2006). In human patients with Timothy syndrome, a G406R point mutation in Cav1.2 increases the channel activity and can lead to excessive insulin secretion and life-threatening hypoglycemia (Splawski et al. 2004). PKA-dependent phosphorylation of Cav1.2 increases channel activity although the exact PKA site responsible for the regulation remains elusive (Weiss et al. 2013). The potentiation of insulin secretion by cAMP is at least partially through PKA-mediated phosphorylation of Cav channels and increased $\mathrm{Ca}^{2+}$ influx (Ammala et al. 1993). More important, PKA can directly enhance insulin exocytosis through phosphorylating secretory granuleassociated proteins such as snapin and synaptotagmin (Fig. 3A) (Seino \& Shibasaki 2005, Song et al. 2011, Wu et al. 2015) to increase $\mathrm{Ca}^{2+}$ responsiveness, and this mechanism may account for the majority of PKA's effect on insulin release (Ammala et al. 1993).

RI $\alpha$-PKA is the most abundant subtype of PKA in mouse pancreatic islets (Petyuk et al. 2008). Selective ablation of RI $\alpha$ in $\beta$ cells leads to disinhibition of PKA and increased phosphorylation of the transcription factor cAMP-response element-binding protein (CREB) (Song et al. 2011). Mice with RI $\alpha$ ablation in $\beta$ cells show greatly enhanced glucose-stimulated insulin secretion and increased glucose tolerance (Song et al. 2011, Hussain et al. 2012). More importantly, human patients with heterozygous RI $\alpha$-inactivating mutation (Carney's complex) also showed increased insulin release during oral glucose tolerance test (Song et al. 2011). Another strategy to increase $\beta$ cell PKA activity is the selective expression of a constitutively active PKA C $\alpha$ subunit in 
A

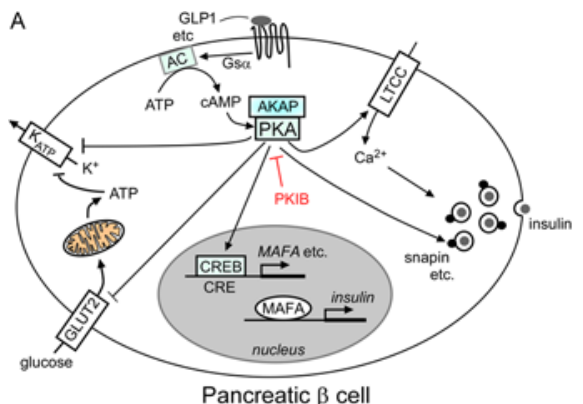

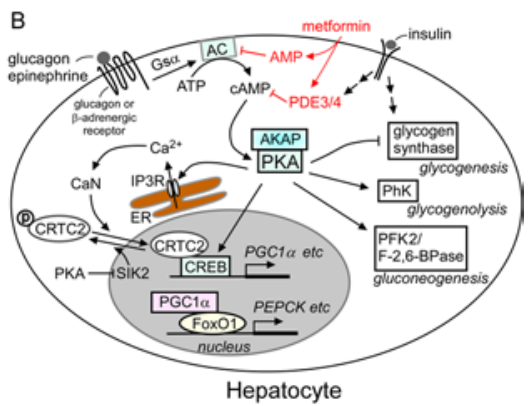

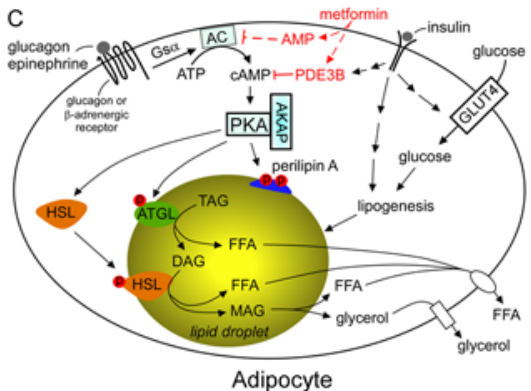

Figure 3

Schematic illustration of the regulation of glucose homeostasis by CAMP/PKA pathway in pancreatic $\beta$ cell, hepatocyte, and adipocyte. (A) Regulation of insulin production by cAMP/PKA signaling in pancreatic $\beta$ cell. Upon stimulation by incretins such as glucagon-like peptide 1 (GLP1), PKA is activated to promote insulin transcription and secretion by phosphorylating the transcription factor CREB, ATP-sensitive potassium channel ( $\mathrm{K}_{\mathrm{ATP}}$ ), glucose transporter GLUT2, L-type voltage-gated calcium channels (LTCC), and secretory vesicle-associated protein snapin. Activated CREB promotes the expression of MAFA, a transcription factor that stimulates the expression of insulin. In conditions of long-term hyperglycemia, insulin secretion is impaired at least partially due to the induction of the intrinsic PKA inhibitor B (PKIB). The effect of PKA on insulin release is also dependent on its subcellular localization that is determined by binding to A-kinase anchoring proteins (AKAPs). (B) Regulation of hepatic glucose production by CAMP/PKA. During a fasting, CAMP/PKA is activated in hepatocytes by glucagon and epinephrine binding to GPCRs. PKA inhibits glycogen synthesis and increases glycogenolysis and gluconeogenesis by phosphorylating glycogen synthase, glycogen phosphorylase kinase (PhK), and phosphofructokinase-2/fructose-2,6-bisphosphatase (PFK2/F-2,6-BPase), respectively (see text for detail). At the transcription level, PKA promotes the expression of gluconeogenic genes such as phosphoenolpyruvate carboxykinase (PEPCK), glucose-6-phosphatase (G6Pase), and PPAR $\gamma$ coactivator-1 $\alpha$ (PGC1 $\alpha$ ) by CREB phosphorylation. PKA also promotes the nuclear import of CAMP-regulated transcriptional coactivator 2 (CRTC2) by stimulating its dephosphorylation (through $\mathrm{IP}_{3}$ receptor $\left(\mathrm{IP}_{3} \mathrm{R}\right)$-calcium-calcineurin $(\mathrm{CaN})$ pathway) and inhibiting its phosphorylation (through phosphorylation and inhibition of salt-inducible kinase SIK2). Insulin and metformin suppress hepatic glucose production at least partially by stimulating the activation of phosphodiesterase (PDE) and downregulation of CAMP signaling. Metformin also increases cellular AMP to inhibit adenylyl cyclase (AC) and thus suppresses cAMP synthesis. (C) Regulation of lipolysis in adipocyte. Glucagon and epinephrine increase lipolysis in adipocytes by stimulating PKAdependent phosphorylation of lipid droplet-associated protein perilipin A, hormone-sensitive lipase (HSL), and adipose triglyceride lipase (ATGL). Insulin promotes glucose uptake and de novo lipogenesis, and inhibits lipolysis by activating PDE3B to suppress CAMP/PKA signaling. Metformin inhibits lipolysis by downregulation of the CAMP/PKA pathway in adipocytes, probably also via AMP and PDE activation. TAG, triacylglycerol; DAG, diacylglycerol; MAG, monoacylglycerol; FFA, free fatty acid.

$\beta$ cells. It has been shown that this enhances both acute and sustained glucose-stimulated insulin release (Kaihara et al. 2013) and improves glucose control in mouse models with diet-induced insulin resistance or streptozotocinmediated glucose intolerance (Kaihara et al. 2015). Importantly, the enhanced insulin release by either RI $\alpha$ ablation or constitutively active mutant $\mathrm{C} \alpha$ expression in $\beta$ cells is not associated with hypoglycemia, suggesting that pancreatic PKA can be a safe target for potential T2D drug development.

By contrast, $\beta$ cell-selective deletion of Gs $\alpha$ in mice leads to severely impaired $\beta$ cell proliferation and reduced insulin expression, accompanied by hyperglycemia and glucose intolerance (Xie et al. 2007), suggesting that cAMP signaling is indispensable for $\beta$ cell physiology. A recent study has shown that cAMP/PKA/CREB signaling promotes insulin transcription by stimulating the expression of transcription factor MAFA (Fig. 3A) (Blanchet et al. 2015). Under conditions of chronic hyperglycemia, PKA signaling is disrupted and insulin expression is suppressed due to the induction of PKA inhibitor $B$ (PKIB) in $\beta$ cells. Mice overexpressing PKIB in pancreatic islets are relatively glucose intolerant and have lower circulating concentrations of insulin during oral glucose tolerance test, whereas $P k i b$-knockout mice are protected from high-fat diet-induced glucose intolerance and 
impairment in insulin release (Blanchet et al. 2015). These results suggested that dysfunctional PKA was involved in the deterioration of $\beta$ cell function during transition from insulin resistance to T2D. Indeed, in patients with T2D, PKIs appear to be upregulated in pancreatic islets (Gunton et al. 2005), suggesting that reducing the expression of PKI can be therapeutically beneficial.

The subcellular localization of PKA in pancreatic $\beta$ cells is also essential for its regulation of insulin secretion and several AKAPs have been identified in $\beta$ cells (Tasken $\&$ Aandahl 2004). Disruption of PKA anchoring to AKAPs with inhibitory peptides suppresses GLP1- and cAMPinduced insulin secretion in pancreatic $\beta$ cells concurrent with decreased $\mathrm{Ca}^{2+}$ accumulation in the cytoplasm (Lester et al. 1997), suggesting that PKA anchoring is required for the regulation of Cav channel activity, $\mathrm{Ca}^{2+}$ influx, or $\mathrm{Ca}^{2+}$ release from internal stores. Selective ablation of AKAP150 in $\beta$ cells leads to reduced L-type $\mathrm{Ca}^{2+}$ influx, suppressed glucose-induced insulin secretion, and impaired glucose tolerance in mice (Hinke et al. 2012), indicating that AKAP150 is required for proper PKA localization in $\beta$ cells. It should be noted that AKAP150 binds type II-PKA (RII $\alpha$ and RII $\beta$ ) with much higher affinity than RI $\alpha$ (Herberg et al. 2000), suggesting that, in addition to RIo-PKA (Hussain et al. 2012), type II PKA may also be involved in the process of insulin secretion. Although RIa is usually considered soluble, dual-specific AKAPs (Jarnaess et al. 2008) that bind both RI and RII subunits and RI-specific AKAPs (Means et al. 2011, Burgers et al. 2012) have been identified. It remains unknown if such an AKAP exists in pancreatic $\beta$ cells to mediate the regulation of insulin secretion by RI $\alpha$-PKA.

\section{$\alpha$ cell}

The whole-body glucose homeostasis is largely dependent on the coordinated secretion of insulin and glucagon by $\beta$ cells and $\alpha$ cells, respectively, in pancreatic islets (Fig. 2). As opposed to insulin, glucagon secretion is increased during fasting to increase blood glucose. The hyperglycemia in diabetic patients has been associated with excessive glucagon levels in the circulation that lead to increased hepatic glucose production (Dunning \& Gerich 2007). Glucagon expression and secretion are regulated by multiple factors including glucose, fatty acids, amino acids, hormones, and neurotransmitters (Quesada et al. 2008). At the transcription level, glucagon expression is promoted by cAMP/PKA/CREB pathway (Knepel et al. 1990, Miller et al. 1993). Somatostatin inhibits the transcription of glucagon potentially by suppressing the cAMP/PKA pathway in a pancreatic cell line (Kendall et al. 1995). Through a positive autocrine feedback mechanism, glucagon increases its own transcription (Leibiger et al. 2012) and secretion (Ma et al. 2005) by stimulating the glucagon receptor/cAMP/PKA/CREB pathway in mouse and human pancreatic islets.

In contrast to its inhibitory effects on $\beta$ cell proliferation and insulin production (Xie et al. 2007), Gs $\alpha$ deficiency promotes the proliferation of $\alpha$ cells without effect on the transcription and serum level of glucagon in mice with pancreas-selective deletion of Gs $\alpha$ (Xie et al. 2010). Normal glucagon expression in the presence of increased $\alpha$ cell numbers suggests that the expression of glucagon per cell is decreased due to Gs $\alpha$ deficiency, indicating that cAMP signaling may have opposite effects on $\alpha$ cell proliferation and glucagon expression.

Similar to insulin, glucagon secretion via exocytosis is also dependent on $\mathrm{Ca}^{2+}$. At basal conditions, low glucoseinduced glucagon secretion requires $\mathrm{Ca}^{2+}$ influx via $\mathrm{N}$-type $\mathrm{Ca}^{2+}$ channels (Gromada et al. 1997). In isolated rat $\alpha$ cells, GLP1 stimulates glucagon secretion by activating cAMP/ PKA (Ding et al. 1997). However, in whole animal and perfused islets, GLP1 inhibits glucagon secretion also in a PKA-dependent manner (Dunning et al. 2005), suggesting that the stimulation of glucagon secretion from isolated $\alpha$ cells is not a physiological effect of GLP1. Further study revealed that the inhibitory effect of GLP1 on glucagon secretion is dependent on PKA-induced phosphorylation and inactivation of $\mathrm{N}$-type $\mathrm{Ca}^{2+}$ channels on $\alpha$ cells (De Marinis et al. 2010). Under conditions with higher cAMP production in the cell, such as during fasting or with adrenaline stimulation, both PKA and Epac are activated and L-type $\mathrm{Ca}^{2+}$ channels are activated and become the major $\mathrm{Ca}^{2+}$ conduit. As a result, glucagon secretion is enhanced (Gromada et al. 1997, De Marinis et al. 2010). This binary regulation of glucagon secretion by GLP1 and adrenaline-elicited cAMP signaling is likely related to the activation of PKA with distinct subcellular localizations within $\alpha$ cells.

\section{CAMP/PKA in the liver}

One essential function of liver is to store and produce glucose to meet the body's needs. Liver is one of the two major sites (another one is skeletal muscle) for glycogen storage and is the main site for glucose release into the circulation during a fasting (Fig. 2). Two main processes contribute to hepatic glucose

Published by Bioscientifica Ltd. 
production (HGP): glycogenolysis and gluconeogenesis. cAMP/PKA signaling in hepatocytes regulates both processes and the synthesis of glycogen as well (Fig. 3B). As stated above, when blood glucose levels drop during an energy deficit, PKA is activated by the binding of glucagon and epinephrine to their Gs-coupled receptors on hepatocytes and acts as the upstream kinase for glycogen phosphorylase kinase (PhK) to promote glycogenolysis in the liver (Berthet et al. 1957). Meanwhile, PKA can phosphorylate glycogen synthase to inhibit its activity and thus suppress the synthesis of glycogen (Proud et al. 1977). When the state of energy deficiency continues, glycogen is depleted and gluconeogenesis is increased to meet the body's glucose demand. The master hormone that promotes gluconeogenesis is glucagon. In hepatocytes, glucagon-induced cAMP/PKA activation promotes gluconeogenesis at multiple levels. A rate-limiting enzyme for gluconeogenesis is fructose-1,6-bisphosphatase (F-1,6BPase) whose activity is suppressed by the powerful negative allosteric effector fructose-2,6-bisphosphate (F-2,6-BP). The level of F-2,6-BP in hepatocytes is determined by the bifunctional enzyme phosphofructokinase-2/fructose-2,6bisphosphatase (PFK2/F-2,6-BPase). PKA phosphorylation of the enzyme turns on the F-2,6-BPase activity leading to dephosphorylation of F-2,6-BP and concomitant increases in F-1,6-BPase activity and gluconeogenesis (Rider et al. 2004). At the level of gene expression, activation of the CAMP/PKA/CREB pathway promotes the expression of several key enzymes and factors to increase gluconeogenesis, including phosphoenolpyruvate carboxykinase (PEPCK) (Quinn 1994, Leahy et al. 1999, Yang et al. 2009), glucose-6-phosphatase (G6Pase) (Streeper et al. 2001), and PPAR $\gamma$ coactivator-1 $\alpha$ (PGC-1 $\alpha$ ) (Herzig et al. 2001, Fernandez-Marcos \& Auwerx 2011). PEPCK and G6Pase are two rate-limiting enzymes for gluconeogenesis. Overexpression of PEPCK in mice leads to increased hepatic glucose production and impaired insulin sensitivity in the liver (Sun et al. 2002). Increased Pepck mRNA levels have been observed in several animal models of T2D and also in human T2D patients (Hanson \& Reshef 1997), although probably not in all T2D patients (Samuel et al. 2009). Increased expression of G6Pase in the liver is also associated with diabetes (Haber et al. 1995, van Schaftingen \& Gerin 2002). PGC1 $\alpha$ is a transcriptional coactivator that plays a central role in the regulation of energy metabolism (Liang \& Ward 2006). In hepatocytes, PGC1 $\alpha$ interacts with other factors such as FOXO1 (Puigserver et al. 2003) to increase the expression of gluconeogenic genes. On the other hand, insulin inhibits hepatic gluconeogenesis at least partially through suppressing CAMP/PKA/CREB pathway to inhibit the expression of PEPCK, G6Pase, and PGC1 $\alpha$ (Fig. 3B) (Park et al. 1972, He et al. 2009).

Another PKA target that is involved in the regulation of hepatic gluconeogenesis is inositol-1,4,5-trisphosphate receptor (IP3R), which forms the main channels for $\mathrm{Ca}^{2+}$ release from endoplasmic reticulum (ER) (Fig. 3B) (Wang et al. 2012). PKA-dependent phosphorylation of IP3Rs increases $\mathrm{Ca}^{2+}$ release and activates the protein phosphatase calcineurin which in turn dephosphorylates cAMP-regulated transcriptional coactivator 2 (CRTC2). Dephosphorylated CRTC2 translocates to the nucleus, where it binds to CREB and stimulates the transcription of gluconeogenic genes. PKA can also promote the activity of CRTC2 by phosphorylation and inactivation of salt-inducible kinase 2 (SIK2) (Altarejos \& Montminy 2011), which phosphorylates CRTC2 and promotes its translocation out of the nucleus.

Hyperglucagonemia-induced increase in liver gluconeogenesis is considered as the main cause of fasting hyperglycemia in T2D (Consoli 1992). Recently, it was shown that metformin, the most widely prescribed T2D medicine, suppresses gluconeogenesis by inhibiting hepatic cAMP/PKA pathway, in addition to the activation of AMP-activated protein kinase (AMPK) (Miller et al. 2013). The study showed that metformin increased cellular level of AMP, which directly inhibited the activity of adenylyl cyclase (Fig. 3B) to suppress glucagon-induced cAMP production and PKA activation. The phosphorylation of two key PKA substrates that promote gluconeogenesis, PFK2 and IP3R, were both reduced after metformin treatment (Miller et al. 2013). Moreover, a recent study has shown that hepatic AMPK can phosphorylate and activate PDE4B to suppress glucagon-mediated cAMP/PKA activation (Johanns et al. 2016), suggesting that metformin inhibits hepatic PKA via multiple pathways. Another study showed that selective inactivation of NF- $\mathrm{\kappa B}$ in mouse liver enhanced insulin sensitivity and suppressed hepatic gluconeogenesis also via inhibition of the cAMP/PKA/CREB pathway (Ke et al. 2015). These studies suggest that cAMP/PKA is the major positive regulator for hepatic gluconeogenesis.

Mice with selective expression of a constitutively active PKA C $\alpha$ R subunit in hepatic cells exhibit decreased levels of liver glycogen, F-2,6-BP content, and glucokinase expression in the fed state, indicating suppressed glycogen synthesis and increased glycogenolysis and gluconeogenesis (Niswender et al. 2005). http://jme.endocrinology-journals.org DOI: 10.1530/JME-15-0316
() 2016 Society for Endocrinology Printed in Great Britain
Published by Bioscientifica Ltd 
These mice exhibit fasting hyperglycemia, impaired glucose tolerance, and defective glucose-induced insulin release (Niswender et al. 2005), suggesting the presence of crosstalk between liver and pancreatic islets. By contrast, mice with selective expression of a dominant-negative PKA RI $\alpha \mathrm{B}$ subunit in hepatic cells exhibit enhanced glucose disposal in glucose-tolerance test, suggesting improved insulin sensitivity in the liver (Willis et al. 2011). The expression of PGC1 $\alpha$, PEPCK, and G6Pase is unchanged despite of dramatically reduced PKA activity in the liver (Willis et al. 2011). The normal levels of expression of gluconeogenic genes in the liver with either $\mathrm{C} \alpha \mathrm{R}$ or $\mathrm{RI} \alpha \mathrm{B}$ expression suggest the existence of compensatory mechanisms during animal development. Temporally conditional manipulations of PKA activity in the liver would be ideal for studying the role of PKA in hepatic gluconeogenic gene expression at the physiological level. Consistent with the effect of RI $\alpha \mathrm{B}$, liver-specific knockout of Gs $\alpha$ in mice leads to improved glucose tolerance and increased insulin sensitivity in liver and skeletal muscle. These mice also had increased glycogen content and decreased expression of gluconeogenic genes in the liver, accompanied by hypoglycemia and more than 100-fold higher blood glucagon levels compared with controls (Chen et al. 2005b), indicating a condition of glucagon resistance. Recently, it was shown that mice with deficiency of the RII $\alpha$ subunit of PKA had decreased PKA activity in the liver and showed resistance to diet-induced insulin resistance and diabetes (London et al. 2014). Collectively, these studies indicate that CAMP/PKA inhibition is not only sufficient but also necessary for efficient insulininduced synthesis of glycogen and suppression of HGP.

\section{cAMP/PKA in skeletal muscle}

Signals via cAMP/PKA pathway control the development (Chen et al. 2005a, Knight \& Kothary 2011) and metabolism (Berdeaux \& Stewart 2012) of skeletal muscle, which plays an essential role in the regulation of glucose homeostasis (Stump et al. 2006). As mentioned above, liver and skeletal muscle are the major sites for glycogen storage. In humans, about $80 \%$ of the glycogen is stored in skeletal muscles (Jensen et al. 2011) because of their much greater mass than the liver. Unlike liver, however, skeletal muscles are unable to release glucose into the blood because muscles lack glucose 6-phosphatase and muscle glycogen is mainly a local energy source for exercise. Exercise-induced glycogen depletion is largely induced by activation of the $\beta$-adrenergic receptor

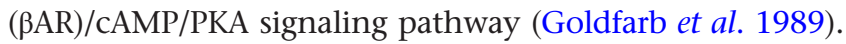
Consistently, exercise is able to increase cAMP level and PKA activity in skeletal muscle (Mehrani \& Storey 1993). Skeletal muscles mainly express $\beta 2$-AR and adrenaline promotes glycogen breakdown through PKA-dependent activation of glycogen phosphorylase and inactivation of glycogen synthase (Cohen 2002). Exercise-induced depletion of muscle glycogen can increase skeletal muscle insulin sensitivity and enhance glycemic control (Jensen et al. 2011).

Skeletal muscle is the major site for insulin-mediated glucose uptake in the postprandial state in humans (DeFronzo et al. 1981, Thiebaud et al. 1982). Skeletal muscle insulin resistance has been suggested as the primary defect in T2D and plays an essential role in the pathogenesis of the disease (DeFronzo \& Tripathy 2009). Insulin stimulates skeletal muscle glucose uptake by increasing translocation of glucose transporter GLUT4 from intracellular vesicles to the plasma membrane and transverse tubules (Zisman et al. 2000). Insulin also increases the synthesis of muscle glycogen by activating glycogen synthase (Cohen 1993). These effects of insulin are at least partially dependent on suppression of muscle PKA activity, and diabetes has been associated with the failure of insulin to inhibit PKA activity in skeletal muscle (Ortmeyer 1997).

Thus, insulin signaling and $\beta$ AR/cAMP/PKA signaling appear to reciprocally regulate each other and have opposite effects on glucose metabolism in skeletal muscle. This is supported by studies showing that epinephrine or norepinephrine inhibits insulin-induced glucose uptake in skeletal muscle (Chiasson et al. 1981, Lembo et al. 1994), while blockade of $\beta$ AR activity increases GLUT4 expression in skeletal muscle and improves insulin sensitivity in diabetic animals (Alves-Wagner et al. 2015). Mice with $\beta A R$ deficiency exhibit increased peripheral insulin sensitivity despite of systemic glucose intolerance because of defective insulin secretion (Asensio et al. 2005). Genetic deletion of adenylyl cyclase 5 (Ac5) also leads to improved glucose tolerance largely due to increased insulin sensitivity in skeletal muscle (Ho et al. 2015). Similarly, sustained stimulation of $\beta 2$-AR leads to cardiac insulin resistance by suppressing GLUT4 expression and glucose uptake in cardiomyocytes in a PKA-dependent manner, suggesting that the mechanism is also present in cardiac muscle (Mangmool et al. 2016).

However, other studies have shown that activation of the $\beta 2-\mathrm{AR} / \mathrm{cAMP} / \mathrm{PKA}$ pathway can also increase glucose uptake in skeletal muscle by promoting GLUT4

Published by Bioscientifica Ltd. 
translocation to the plasma membrane in an insulinindependent manner (Ngala et al. 2013, Sato et al. 2014). The controversial results may be related to different physiological conditions: in the postprandial and rest state, when insulin level is increased, $\beta \mathrm{AR} / \mathrm{cAMP} / \mathrm{PKA}$ pathway is usually suppressed to facilitate anabolic processes in skeletal muscles; activation of the $\beta A R / c A M P / P K A$ pathway at this time would antagonize the actions of insulin and lead to insulin resistance. In conditions of exercise or fasting, insulin level is low and $\beta \mathrm{AR} / \mathrm{cAMP} / \mathrm{PKA}$ system is activated to promote catabolic processes to meet the energy demands of skeletal muscles. The increased muscle glucose uptake by activation of $\beta 2-\mathrm{AR} / \mathrm{cAMP} / \mathrm{PKA}$ pathway could be a mechanism to provide energy substrate for muscle activity in the latter conditions. In T2D patients with insulin resistance, selective activation of PKA in skeletal muscle can serve as an alternative pathway for glucose disposal and glycemic control.

Consistent with the role of cAMP signaling in skeletal muscle development and systemic glucose homeostasis, Gs $\alpha$ deficiency in skeletal muscles leads to reduced skeletal muscle mass and impaired glucose tolerance, although muscle insulin sensitivity is intact (Chen et al. 2009a). PDE4 is a cAMP-selective hydrolase and is the predominant PDE subtype in skeletal muscle. The inhibition of muscle PDE4 at least partially accounts for the beneficial effects of resveratrol on metabolism, including improved glucose tolerance, by activation of cAMP/Epac/Sirt1 pathway (Park et al. 2012). Whether PKA is involved in this process remains unknown, but it should be noted that PKA can directly phosphorylate and activate SIRT1 in skeletal muscles (Gerhart-Hines et al. 2011). Consistently, PDE content in skeletal muscle is positively related to fasting plasma glucose level in diabetic patients (Szendroedi et al. 2011), suggesting a correlation between suppressed cAMP signaling and impaired glucose homeostasis. Generation of mouse models with conditional loss- or gain-of-function of cAMP signaling components such as PDE4, EPAC1, and PKA specifically in skeletal muscle will provide further insights into the physiological role of muscle cAMP signaling in glycemic control.

Insulin resistance are often associated with increased lipid accumulation and impaired lipid oxidation in skeletal muscle (Turcotte \& Fisher 2008). Pharmacological or physiological stimulation of $\beta$-adrenergic signaling in skeletal muscle leads to PKA-dependent activation of SIRT1 which promotes fatty acid oxidation and energy expenditure (Gerhart-Hines et al. 2011). The monounsaturated fatty acid oleic acid is able to improve skeletal muscle insulin resistance partially through a PKAdependent mechanism (Coll et al. 2008). Specifically, oleic acid can activate PKA/Sirt1/PGC1 $\alpha$ pathway to stimulate fatty acid oxidation in skeletal muscle (Lim et al. 2013). These data suggest that PKA is positively associated with lipid oxidation and insulin sensitivity in skeletal muscle.

Taken together, these genetic and pharmacological studies have shown that appropriately regulated cAMP/PKA activity is essential for skeletal muscle insulin sensitivity and systemic glucose homeostasis.

\section{CAMP/PKA in adipose tissues}

Adipose tissues are crucial regulators for energy balance and glucose homeostasis through actions in glucose uptake, lipid metabolism, and hormone secretion (Rosen \& Spiegelman 2006). Adipose tissues account for only about $10 \%$ of insulin-mediated glucose uptake; however, selective GLUT4 deletion in adipose tissues leads to glucose intolerance and insulin resistance in muscle and liver (Abel et al. 2001). By contrast, adiposespecific overexpression of GLUT4 enhances systemic insulin sensitivity and reverses diabetes in mice with muscle-specific GLUT4 deficiency (Carvalho et al. 2005), suggesting that adipose glucose uptake can compensate for defective muscle glucose uptake. In addition to insulin, norepinephrine can also increase glucose uptake in both white (WAT) and brown adipose tissues (BAT) (Liu et al. $1994)$, potentially by activation of the $\beta 3-\mathrm{AR} / \mathrm{cAMP} / \mathrm{PKA}$ pathway (Chernogubova et al. 2004).

CAMP/PKA signaling is the major positive regulator of lipolysis in WAT and BAT (Fig. 3C). PKA promotes lipolysis by phosphorylating several proteins including lipid droplet-associated protein perilipin A (Miyoshi et al. 2007), hormone-sensitive lipase (HSL) (Krintel et al. 2008), and adipose triglyceride lipase (ATGL) (Pagnon et al. 2012). In normal fed condition, insulin promotes lipogenesis and suppresses lipolysis partially through inhibition of cAMP/PKA signaling by activation of PDE3B in adipocyte (Eriksson et al. 1995, Kitamura et al. 1999). Obesity is associated with increased basal lipolysis and elevated levels of serum free fatty acids (FFAs) that contribute to insulin resistance (Bergman \& Ader 2000). In diabetic patients with obesity, metformin improves insulin sensitivity by decreasing circulating FFAs (Abbasi et al. 1998). Further study showed that metformin inhibits lipolysis by suppressing cAMP production and PKA activation in adipocytes (Zhang et al. 2009). Thus, metformin exerts its antidiabetic effects by inhibiting

Published by Bioscientifica Ltd. 
cAMP/PKA signaling in both adipose tissue and liver to suppress excessive lipolysis and glucose production, respectively.

RII $\beta$ is the major PKA subtype in adipose tissues in mouse (Cummings et al. 1996) and human (Mantovani et al. 2009, Peverelli et al. 2013). In mice, RII $\beta$ deficiency is associated with compensatory increase in RI $\alpha$ PKA and increased basal PKA activity in WAT and BAT. $\beta A R$-stimulated lipolysis is impaired but the basal rate of lipolysis is increased in the WAT of Rii $\beta$-knockout mice (Planas et al. 1999). In BAT, RII $\beta$ deficiency leads to increases in mitochondrial content and thermogenesis (Nolan et al. 2004, Newhall et al. 2005). However in human, obesity is associated with reduced RII $\beta$ expression and PKA activity in WAT (Mantovani et al. 2009). $\beta$ AR-stimulated lipolysis and mitochondrial respiration are also decreased in WAT of obese patients (Yehuda-Shnaidman et al. 2010). In 3T3-L1 adipocytes, it has been shown that the anchoring of PKA to AKAP is required for $\beta$ AR-stimulated lipolysis (Pidoux et al. 2011). These results suggest that RII $\beta$-PKA is required for $\beta A R$-stimulated lipolysis in the WAT of both mouse and human and impaired adipose RII $\beta$-PKA signaling may contribute to human obesity.

Deletion of $\mathrm{Gs} \alpha$ in mouse adipocytes leads to decreased lipogenesis and lipolysis, increased muscle insulin sensitivity, and improved glucose tolerance (Chen et al. 2010, Li et al. 2016). The increased insulin sensitivity is likely caused by decreased circulating lipids and lower fat contents in muscle and liver, because insulin-mediated glucose uptake in adipose tissues is suppressed by Gs $\alpha$ deficiency ( $\mathrm{Li}$ et al. 2016). Interestingly, Gs $\alpha$ deletion in mature adipocytes has no overall effect on fat content and body weight despite of impaired BAT and WAT functions (Li et al. 2016). However, deletion of $\mathrm{Gs} \alpha$ in preadipocytes from an earlier developmental stage leads to leanness with impaired adipocyte differentiation (Chen et al. 2010). These data suggest that cAMP signaling in mature adipocytes affects glucose homeostasis mainly by regulating lipid metabolism.

Glucose homeostasis is also closely regulated by adipokines produced by adipocytes, such as leptin and adiponectin (Rosen \& Spiegelman 2006, Coppari $\&$ Bjorbaek 2012). Leptin expression and secretion is enhanced by insulin but suppressed by the activation of cAMP/PKA signaling (Szkudelski et al. 2005, Maeda $\&$ Horiuchi 2009). The expression of adiponectin has been shown to be positively regulated by PKA (Otani et al. 2015) and CREB signaling in 3T3-L1 adipocytes (Kim et al. 2010), whereas other studies suggested that $\beta A R / P K A$ signaling inhibits adiponectin expression in these cells (Fasshauer et al. 2001). Further studies are needed to determine if $\mathrm{CAMP} / \mathrm{PKA}$ signaling regulates the expression of these adipokines in vivo.

\section{CAMP/PKA in the brain}

The brain regulates energy balance and glucose homeostasis through cooperation with peripheral tissues including fat, pancreatic islets, and liver (Morton \& Schwartz 2011, Grayson et al. 2013, Schwartz et al. 2013, Rojas \& Schwartz 2014, Scarlett \& Schwartz 2015). Leptin, a fat-derived hormone, regulates food intake, energy expenditure, and glucose homeostasis mainly by its actions on hypothalamic neurons (Morton \& Schwartz 2011). Insulin also acts in the brain to regulate food intake and HGP (Gray et al. 2014, Rojas \& Schwartz 2014). In hypothalamic neurons, cAMP signaling is modulated by several hormones including leptin and insulin to affect food intake (Zhao 2005). A recent study found that glucagon acts in the hypothalamus to inhibit HGP by a PKA-dependent mechanism (Mighiu etal.2013). Inhibition of PKA activity in the mediobasal hypothalamus (MBH) abolishes the suppressive effect of glucagon on HGP and leads to increased i.v. glucagon injection-induced HGP. By contrast, activation of PKA in $\mathrm{MBH}$ inhibits HGP and resembles the effects of glucagon injection to the hypothalamus. The glucagon-induced activation of hypothalamic PKA and inhibition of HGP are both attenuated in rats fed a high-fat diet, whereas activation of PKA by Sp-cAMPS infusion to MBH can still efficiently inhibit HGP in these rats (Mighiu et al. 2013). These findings suggest that hypothalamic glucagon resistance contributes to increased HGP and hyperglycemia in diabetes and obesity and that pharmacological activation of PKA in $\mathrm{MBH}$ can bypass the glucagon resistance with therapeutic potential for diabetes treatment.

The gene encoding Gs $\alpha$ (GNAS) shows parentalspecific imprinting and patients with maternal inactive mutations exhibit obesity and insulin resistance (Weinstein 2014). Animal studies have shown that brain-specific maternal Gs $\alpha$ mutation leads to obesity, severe insulin resistance, and diabetes (Chen et al. $2009 b$ ). Especially, these mice developed insulin-resistant diabetes before the development of obesity, indicating that central Gs $\alpha$ signaling directly regulates peripheral glucose metabolism. Specific maternal Gs $\alpha$ deficiency in paraventricular nucleus of the hypothalamus leads to milder obesity and has marginal effects on glucose http://jme.endocrinology-journals.org DOI: 10.1530/JME-15-0316
() 2016 Society for Endocrinology Printed in Great Britain
Published by Bioscientifica Ltd 
homeostasis (Chen et al. 2012). By contrast, Gs $\alpha$ deletion selectively in ventromedial hypothalamic neurons leads to improved glucose homeostasis especially when the mice fed a high-fat diet (Berger et al. 2016). Thus, the specific neuronal populations that mediate the negative effects of Gs $\alpha$ mutations on glucose homeostasis remain to be determined. As discussed above, Gs $\alpha$ deficiency in glucagon-responsive neurons in $\mathrm{MBH}$ can lead to central glucagon resistance and contribute to the development of hyperglycemia and diabetes.

In mouse hypothalamus, multiple PKA $\mathrm{R}$ and $\mathrm{C}$ subunits are expressed with RII $\beta$-PKA as one of the major subtypes (Yang \& McKnight 2015). Mice with global knockout of RII $\beta$ subunit exhibit leanness, elevated insulin and leptin sensitivity, and resistance to diet-induced obesity and diabetes (Schreyer et al. 2001, Enns et al. 2009b, Yang \& McKnight 2015). The lean phenotype and likely the improved glucose metabolism as well are caused by RIIB-PKA deficiency in the hypothalamus (Zheng et al. 2013). RII $\beta$ deficiency leads to reduced PKA $C \alpha$ and $C \beta$ subunits and decreased total PKA activity in multiple brain regions (Brandon et al. 1998, Yang \& McKnight 2015) that is accompanied by a compensatory increase in type I PKA. This shift from type II to type I PKA leads to increased sensitivity to activation by cAMP (Brandon et al. 1998) and likely altered the intracellular localization of PKA as well. Leanness and increased insulin sensitivity have also been observed in mice lacking PKA C $\beta$ subunits, which are highly expressed in the hypothalamus (Guthrie et al. 1997, Enns et al. 2009a). C $\beta$ deficiency reduces basal PKA activity, but has no significant effect on total PKA activity in some brain regions due to a compensatory increase in $\mathrm{C} \alpha$ subunits (Howe et al. 2002). It remains unknown to what extent PKA activity is impaired by $\mathrm{C} \beta$ deficiency in hypothalamic regions that are essential for the regulation of energy balance. Generation of conditional mutant mice lacking $C \beta$ in specific types of neurons will provide more mechanistic insights. Although the neuronal populations and molecular mechanisms responsible for the improved glucose metabolism in RII $\beta$ KO and $\mathrm{C} \beta$ KO mice remain largely unknown, these findings suggest that PKA manipulations in the brain, most likely in hypothalamic neurons, has the potential to improve glycemic control in diabetes.

\section{Strategies for CAMP/PKA pathway targeting}

Recent findings have supported the feasibility of cAMP/PKA pathway as a target for treatment of a variety of diseases, such as cancers (Chochung 1993, Tortora \& Ciardiello 2003, Sapio et al. 2014), polycystic kidney disease (Torres \& Harris 2014), cardiovascular diseases (Lee et al. 2013), and diabetes (Miller et al. 2013). Several strategies have been proposed for cAMP/PKA pathway targeting, including the following: (1) modulation of cAMP levels. As an example, metformin inhibits hepatic gluconeogenesis by suppressing glucagon-induced cAMP production in hepatocytes (Miller et al. 2013). Another class of drugs that have been clinically prescribed or in clinical trials for T2D treatment are GPCR agonists or antagonists (Ahren 2009). For example, the GLP1R agonists exenatide (Byetta) and liraglutide (Victoza) are FDA-approved antidiabetic drugs and are able to enhance insulin secretion by stimulating cAMP production in $\beta$ cells. Small molecular antagonists for glucagon receptor are under preclinical or clinical investigations for their inhibitory effects on HGP (Sammons \& Lee 2015). cAMPdegrading PDEs have been suggested as antidiabetic targets (Furman \& Pyne 2006). Inhibitors for PDE4 has been recently shown to be able to improve glucose homeostasis in diabetic mice (Vollert et al. 2012) and human patients (Wouters et al. 2012), potentially by enhancing cAMP-mediated GLP1 secretion (Vollert et al. 2012); (2) inhibition of PKA. Small molecular inhibitors for PKA such as H89 and KT 5720 have exhibited beneficial effects in animal models of cardiac diseases (Oddis et al. 1996, Makaula et al. 2005). The specificity of these inhibitors, however, is questioned (Murray 2008). A more specific approach for PKA manipulation, antisense oligonucleotide-based knockdown of PKA R subunit, has shown anticancer effects in preclinical (Tortora et al. 1997) and clinical studies (Goel et al. 2006). It remains unknown if these strategies have any effect on glucose control in animal models or human patients with T2D; and (3) disruption of AKAP signaling complexes. AKAPs interact with PKA, PDEs, and protein phosphatases to ensure their appropriate intracellular localization and facilitate signal transduction, specificity, and termination. The signaling complexes have been suggested as potential drug targets for cancers, chronic heart failure, diabetes, etc. (Alto et al. 2002, Troger et al. 2012, Esseltine \& Scott 2013). Although peptide disruptors for AKAP-PKA interaction have been extensively studied in research, validated small molecule disruptors suitable for therapeutic purposes are still lacking and under investigation (Troger et al. 2012). Another approach to suppress AKAP-mediated signaling is small interference RNA (siRNA)-mediated knockdown of AKAP expression (Josefsen et al. 2010). http://jme.endocrinology-journals.org DOI: 10.1530/JME-15-0316
(C) 2016 Society for Endocrinology Printed in Great Britain
Published by Bioscientifica Ltd 


\section{Concluding remarks}

In summary, cAMP/PKA signaling in different tissues has pleiotropic effects on whole-body glucose homeostasis and regulates glucose metabolism at multiple levels. Genetic and pharmacological studies in animal models suggest that selective activation of cAMP/PKA pathway in pancreatic $\beta$ cells or selective inhibition of cAMP/PKA pathway in liver can be safe and effective in improving glycemic control in T2D. Activation of $\beta A R / c A M P / P K A$ pathway in skeletal muscle is coupled to glycogen breakdown and lipolysis and positively regulates glucose homeostasis. However, chronic overactivation of the sympathetic nervous system is associated with increased basal lipolysis in adipose tissue and may contribute to insulin resistance in obesity and diabetes. Inhibition of cAMP/PKA in fat tissue has been suggested to contribute to the insulin-sensitizing effect of metformin via suppression of lipolysis and circulating FFAs. In the hypothalamus, cAMP/PKA pathway has profound effects on energy balance and glucose homeostasis that merit further studies. Although it is clinically challenging to yield tissue-specific manipulation of cAMP/PKA pathway, the findings that metformin exerts its antidiabetic effect by inhibiting hepatic cAMP/PKA/CREB pathway (He et al. 2009, Miller et al. 2013, Pernicova \& Korbonits 2014) strongly support this signaling cascade as a target for the development of new T2D therapeutics.

\section{Declaration of interest}

The authors declare that there is no conflict of interest that could be perceived as prejudicing the impartiality of this review.

\section{Funding}

This work was partially supported by US National Institutes of Health (NIH R01 GM32875).

\section{Acknowledgment}

The authors thank Ying Lai for help with manuscript editing.

\section{References}

Abbasi F, Carantoni M, Chen YD \& Reaven GM 1998 Further evidence for a central role of adipose tissue in the antihyperglycemic effect of metformin. Diabetes Care 21 1301-1305. (doi:10.2337/ diacare.21.8.1301)

Abel ED, Peroni O, Kim JK, Kim YB, Boss O, Hadro E, Minnemann T, Shulman GI \& Kahn BB 2001 Adipose-selective targeting of the GLUT4 gene impairs insulin action in muscle and liver. Nature 409 729-733. (doi:10.1038/35055575)
Ahren B 2009 Islet G protein-coupled receptors as potential targets for treatment of type 2 diabetes. Nature Reviews. Drug Discovery 8 369-385. (doi:10.1038/nrd2782)

Almahariq M, Mei FC \& Cheng X 2014 Cyclic AMP sensor EPAC proteins and energy homeostasis. Trends in Endocrinology and Metabolism 25 60-71. (doi:10.1016/j.tem.2013.10.004)

Altarejos JY \& Montminy M 2011 CREB and the CRTC co-activators: sensors for hormonal and metabolic signals. Nature Reviews. Molecular Cell Biology 12 141-151. (doi:10.1038/nrm3072)

Alto N, Carlisle Michel JJ, Dodge KL, Langeberg LK \& Scott JD 2002 Intracellular targeting of protein kinases and phosphatases. Diabetes 51 S385-388. (doi:10.2337/diabetes.51.2007.S385)

Alves-Wagner AB, Mori RC, Sabino-Silva R, Fatima LA, Alves Ada S, Britto LR, Schaan BD \& Machado UF 2015 Beta-adrenergic blockade increases GLUT4 and improves glycemic control in insulin-treated diabetic Wistar rats. Autonomic Neuroscience 193 108-116. (doi:10.1016/j.autneu.2015.10.003)

Ammala C, Ashcroft FM \& Rorsman P 1993 Calcium-independent potentiation of insulin release by cyclic AMP in single beta-cells. Nature 363 356-358. (doi:10.1038/363356a0)

Antos CL, Frey N, Marx SO, Reiken S, Gaburjakova M, Richardson JA, Marks AR \& Olson EN 2001 Dilated cardiomyopathy and sudden death resulting from constitutive activation of protein kinase a. Circulation Research 89 997-1004. (doi:10.1161/hh2301.100003)

Asensio C, Jimenez M, Kuhne F, Rohner-Jeanrenaud F \& Muzzin P 2005 The lack of beta-adrenoceptors results in enhanced insulin sensitivity in mice exhibiting increased adiposity and glucose intolerance. Diabetes 54 3490-3495. (doi:10.2337/diabetes.54.12.3490)

Beebe SJ, Oyen O, Sandberg M, Froysa A, Hansson V \& Jahnsen T 1990 Molecular cloning of a tissue-specific protein kinase ( $\mathrm{C}$ gamma) from human testis-representing a third isoform for the catalytic subunit of cAMP-dependent protein kinase. Molecular Endocrinology 4 465-475. (doi:10.1210/mend-4-3-465)

Beguin P, Nagashima K, Nishimura M, Gonoi T \& Seino S 1999 PKAmediated phosphorylation of the human K(ATP) channel: separate roles of Kir6.2 and SUR1 subunit phosphorylation. EMBO Journal 18 4722-4732. (doi:10.1093/emboj/18.17.4722)

Berdeaux R \& Stewart R 2012 cAMP signaling in skeletal muscle adaptation: hypertrophy, metabolism, and regeneration. American Journal of Physiology: Endocrinology and Metabolism 303 E1-E17. (doi:10.1152/ajpendo.00555.2011)

Berger A, Kablan A, Yao C, Ho T, Podyma B, Weinstein LS \& Chen M 2016 Gsalpha deficiency in the ventromedial hypothalamus enhances leptin sensitivity and improves glucose homeostasis in mice on a high-fat diet. Endocrinology 157 600-610. (doi:10.1210/en.2015-1700)

Bergman RN \& Ader M 2000 Free fatty acids and pathogenesis of type 2 diabetes mellitus. Trends in Endocrinology and Metabolism 11 351-356. (doi:10.1016/S1043-2760(00)00323-4)

Berthet J, Rall TW \& Sutherland EW 1957 The relationship of epinephrine and glucagon to liver phosphorylase. IV. Effect of epinephrine and glucagon on the reactivation of phosphorylase in liver homogenates. Journal of Biological Chemistry 224 463-475.

Blanchet E, Van de Velde S, Matsumura S, Hao E, LeLay J, Kaestner K \& Montminy M 2015 Feedback inhibition of CREB signaling promotes beta cell dysfunction in insulin resistance. Cell Reports $\mathbf{1 0}$ 1149-1157. (doi:10.1016/j.celrep.2015.01.046)

Brandon EP, Logue SF, Adams MR, Qi M, Sullivan SP, Matsumoto AM, Dorsa DM, Wehner JM, McKnight GS \& Idzerda RL 1998 Defective motor behavior and neural gene expression in RIIbeta-protein kinase A mutant mice. Journal of Neuroscience 18 3639-3649.

Burgers PP, Ma Y, Margarucci L, Mackey M, van der Heyden MA, Ellisman M, Scholten A, Taylor SS \& Heck AJ 2012 A small novel A-kinase anchoring protein (AKAP) that localizes specifically protein kinase A-regulatory subunit I (PKA-RI) to the plasma membrane. Journal of Biological Chemistry 287 43789-43797. (doi:10.1074/jbc. M112.395970)

Published by Bioscientifica Ltd. 
Carvalho E, Kotani K, Peroni OD \& Kahn BB 2005 Adipose-specific overexpression of GLUT4 reverses insulin resistance and diabetes in mice lacking GLUT4 selectively in muscle. American Journal of Physiology: Endocrinology and Metabolism 289 E551-561. (doi:10.1152/ ajpendo.00116.2005)

Chen AE, Ginty DD \& Fan CM 2005a Protein kinase A signalling via CREB controls myogenesis induced by Wnt proteins. Nature $\mathbf{4 3 3}$ 317-322. (doi:10.1038/nature03126)

Chen M, Gavrilova O, Zhao WQ, Nguyen A, Lorenzo J, Shen L, Nackers L, Pack S, Jou W \& Weinstein LS 2005b Increased glucose tolerance and reduced adiposity in the absence of fasting hypoglycemia in mice with liver-specific Gs alpha deficiency. Journal of Clinical Investigation 115 3217-3227. (doi:10.1172/JCI24196)

Chen M, Feng HZ, Gupta D, Kelleher J, Dickerson KE, Wang J, Hunt D, Jou W, Gavrilova O, Jin JP, et al. 2009a G(s)alpha deficiency in skeletal muscle leads to reduced muscle mass, fiber-type switching, and glucose intolerance without insulin resistance or deficiency. American Journal of Physiology: Cell Physiology 296 C930-C940. (doi:10.1152/ajpcell.00443.2008)

Chen M, Wang J, Dickerson KE, Kelleher J, Xie T, Gupta D, Lai EW, Pacak K, Gavrilova O \& Weinstein LS 2009b Central nervous system imprinting of the $\mathrm{G}$ protein $\mathrm{G}(\mathrm{s})$ alpha and its role in metabolic regulation. Cell Metabolism 9 548-555. (doi:10.1016/j.cmet.2009.05.004)

Chen M, Chen H, Nguyen A, Gupta D, Wang J, Lai EW, Pacak K, Gavrilova O, Quon MJ \& Weinstein LS 2010 G(s)alpha deficiency in adipose tissue leads to a lean phenotype with divergent effects on cold tolerance and diet-induced thermogenesis. Cell Metabolism $\mathbf{1 1}$ 320-330. (doi:10.1016/j.cmet.2010.02.013)

Chen M, Berger A, Kablan A, Zhang J, Gavrilova O \& Weinstein LS 2012 Gsalpha deficiency in the paraventricular nucleus of the hypothalamus partially contributes to obesity associated with Gsalpha mutations. Endocrinology 153 4256-4265. (doi:10.1210/ en.2012-1113)

Chen PC, Kryukova YN \& Shyng SL 2013 Leptin regulates KATP channel trafficking in pancreatic beta-cells by a signaling mechanism involving AMP-activated protein kinase (AMPK) and cAMPdependent protein kinase (PKA). Journal of Biological Chemistry 288 34098-34109. (doi:10.1074/jbc.M113.516880)

Chernogubova E, Cannon B \& Bengtsson T 2004 Norepinephrine increases glucose transport in brown adipocytes via beta3adrenoceptors through a cAMP, PKA, and PI3-kinase-dependent pathway stimulating conventional and novel PKCs. Endocrinology 145 269-280. (doi:10.1210/en.2003-0857)

Chiasson JL, Shikama H, Chu DT \& Exton JH 1981 Inhibitory effect of epinephrine on insulin-stimulated glucose uptake by rat skeletal muscle. Journal of Clinical Investigation 68 706-713. (doi:10.1172/ JCI110306)

Chochung Y 1993 Differentiation therapy of cancer targeting the ri-alpha regulatory subunit of cAMP-dependent protein-kinase (review). International Journal of Oncology 3 141-148. (doi:10.3892/ijo.3.2.141)

Cohen P 1993 Dissection of the protein phosphorylation cascades involved in insulin and growth factor action. Biochemical Society Transactions 21 555-567. (doi:10.1042/bst0210555)

Cohen P 2002 The origins of protein phosphorylation. Nature Cell Biology 4 E127-E130. (doi:10.1038/ncb0502-e127)

Coll T, Eyre E, Rodriguez-Calvo R, Palomer X, Sanchez RM, Merlos M, Laguna JC \& Vazquez-Carrera M 2008 Oleate reverses palmitate-induced insulin resistance and inflammation in skeletal muscle cells. Journal of Biological Chemistry 283 11107-11116. (doi:10.1074/jbc.M708700200)

Consoli A 1992 Role of liver in pathophysiology of NIDDM. Diabetes Care 15 430-441. (doi:10.2337/diacare.15.3.430)

Coppari R \& Bjorbaek C 2012 Leptin revisited: its mechanism of action and potential for treating diabetes. Nature Reviews. Drug Discovery 11 692-708. (doi:10.1038/nrd3757)

Cummings DE, Brandon EP, Planas JV, Motamed K, Idzerda RL \& McKnight GS 1996 Genetically lean mice result from targeted disruption of the RII beta subunit of protein kinase A. Nature 382 622-626. (doi:10.1038/382622a0)

De Marinis YZ, Salehi A, Ward CE, Zhang Q, Abdulkader F, Bengtsson M, Braha O, Braun M, Ramracheya R, Amisten S, et al. 2010 GLP-1 inhibits and adrenaline stimulates glucagon release by differential modulation of N- and L-type Ca2+ channel-dependent exocytosis. Cell Metabolism 11 543-553. (doi:10.1016/j.cmet.2010.04.007)

DeFronzo RA, Ferrannini E, Sato Y, Felig P \& Wahren J 1981 Synergistic interaction between exercise and insulin on peripheral glucose uptake. Journal of Clinical Investigation 68 1468-1474. (doi:10.1172/JCI110399)

DeFronzo RA \& Tripathy D 2009 Skeletal muscle insulin resistance is the primary defect in type 2 diabetes. Diabetes Care 32 S157-S163. (doi:10.2337/dc09-S302)

Ding WG, Renstrom E, Rorsman P, Buschard K \& Gromada J 1997 Glucagon-like peptide I and glucose-dependent insulinotropic polypeptide stimulate $\mathrm{Ca} 2+$-induced secretion in rat alpha-cells by a protein kinase A-mediated mechanism. Diabetes 46 792-800. (doi:10.2337/diab.46.5.792)

Dunning BE \& Gerich JE 2007 The role of alpha-cell dysregulation in fasting and postprandial hyperglycemia in type 2 diabetes and therapeutic implications. Endocrine Reviews 28 253-283. (doi:10.1210/er.2006-0026)

Dunning BE, Foley JE \& Ahren B 2005 Alpha cell function in health and disease: influence of glucagon-like peptide-1. Diabetologia 48 1700-1713. (doi:10.1007/s00125-005-1878-0)

Enns LC, Morton JF, Mangalindan RS, McKnight GS, Schwartz MW, Kaeberlein MR, Kennedy BK, Rabinovitch PS \& Ladiges WC $2009 a$ Attenuation of age-related metabolic dysfunction in mice with a targeted disruption of the Cbeta subunit of protein kinase A. Journals of Gerontology. Series A, Biological Sciences and Medical Sciences 64 1221-1231. (doi:10.1093/gerona/glp133)

Enns LC, Morton JF, Treuting PR, Emond MJ, Wolf NS, McKnight GS, Rabinovitch PS \& Ladiges WC $2009 b$ Disruption of protein kinase A in mice enhances healthy aging. PLOS ONE 4 e5963. (doi:10.1371/ journal.pone.0005963)

Enns LC, Bible KL, Emond MJ \& Ladiges WC 2010 Mice lacking the Cbeta subunit of PKA are resistant to angiotensin II-induced cardiac hypertrophy and dysfunction. BMC Research Notes 3307. (doi:10.1186/1756-0500-3-307)

Eriksson H, Ridderstrale M, Degerman E, Ekholm D, Smith CJ, Manganiello VC, Belfrage P \& Tornqvist H 1995 Evidence for the key role of the adipocyte cGMP-inhibited cAMP phosphodiesterase in the antilipolytic action of insulin. Biochimica et Biophysica Acta 1266 101-107. (doi:10.1016/0167-4889(94)00237-9)

Esseltine JL \& Scott JD 2013 AKAP signaling complexes: pointing towards the next generation of therapeutic targets? Trends in Pharmacological Sciences 34 648-655. (doi:10.1016/j.tips.2013.10.005)

Fasshauer M, Klein J, Neumann S, Eszlinger M \& Paschke R 2001 Adiponectin gene expression is inhibited by beta-adrenergic stimulation via protein kinase A in 3T3-L1 adipocytes. FEBS Letters 507 142-146. (doi:10.1016/S0014-5793(01)02960-X)

Fernandez-Marcos PJ \& Auwerx J 2011 Regulation of PGC-1alpha, a nodal regulator of mitochondrial biogenesis. American Journal of Clinical Nutrition 93 884S-890. (doi:10.3945/ajcn.110.001917)

Furman B \& Pyne N 2006 Modulation of cyclic nucleotides and cyclic nucleotide phosphodiesterases in pancreatic islet beta-cells and intestinal L-cells as targets for treating diabetes mellitus. Current Opinion in Investigational Drugs 7 898-905.

Furman B, Ong WK \& Pyne NJ 2010 Cyclic AMP signaling in pancreatic islets. Advances in Experimental Medicine and Biology 654 281-304. (doi:10.1007/978-90-481-3271-3)

Gerhart-Hines Z, Dominy JE Jr, Blattler SM, Jedrychowski MP, Banks AS, Lim JH, Chim H, Gygi SP \& Puigserver P 2011 The cAMP/PKA pathway rapidly activates SIRT1 to promote fatty acid oxidation independently of changes in NAD(+). Molecular Cell 44 851-863. (doi:10.1016/j.molcel.2011.12.005)

Published by Bioscientifica Ltd. 
Goel S, Desai K, Macapinlac M, Wadler S, Goldberg G, Fields A, Einstein M, Volterra F, Wong B, Martin R, et al. 2006 A phase I safety and dose escalation trial of docetaxel combined with GEM231, a second generation antisense oligonucleotide targeting protein kinase A R1alpha in patients with advanced solid cancers. Investigational New Drugs 24 125-134. (doi:10.1007/s10637-006-2378-x)

Goldfarb AH, Bruno JF \& Buckenmeyer PJ 1989 Intensity and duration of exercise effects on skeletal muscle cAMP, phosphorylase, and glycogen. Journal of Applied Physiology 66 190-194.

Gray SM, Meijer RI \& Barrett EJ 2014 Insulin regulates brain function, but how does it get there? Diabetes 63 3992-3997. (doi:10.2337/ db14-0340)

Grayson BE, Seeley RJ \& Sandoval DA 2013 Wired on sugar: the role of the CNS in the regulation of glucose homeostasis. Nature Reviews. Neuroscience 14 24-37. (doi:10.1038/nrn3409)

Gromada J, Bokvist K, Ding WG, Barg S, Buschard K, Renstrom E \& Rorsman P 1997 Adrenaline stimulates glucagon secretion in pancreatic A-cells by increasing the $\mathrm{Ca} 2+$ current and the number of granules close to the L-type Ca2+ channels. Journal of General Physiology 110 217-228. (doi:10.1085/jgp.110.3.217)

Gunton JE, Kulkarni RN, Yim S, Okada T, Hawthorne WJ, Tseng YH, Roberson RS, Ricordi C, O'Connell PJ, Gonzalez FJ, et al. 2005 Loss of ARNT/HIF1beta mediates altered gene expression and pancreaticislet dysfunction in human type 2 diabetes. Cell 122 337-349. (doi:10.1016/j.cell.2005.05.027)

Guthrie CR, Skalhegg BS \& McKnight GS 1997 Two novel brain-specific splice variants of the murine Cbeta gene of cAMP-dependent protein kinase. Journal of Biological Chemistry 272 29560-29565. (doi:10.1074/jbc.272.47.29560)

Haber BA, Chin S, Chuang E, Buikhuisen W, Naji A \& Taub R 1995 High levels of glucose-6-phosphatase gene and protein expression reflect an adaptive response in proliferating liver and diabetes. Journal of Clinical Investigation 95 832-841. (doi:10.1172/JCI117733)

Hanson RW \& Reshef L 1997 Regulation of phosphoenolpyruvate carboxykinase (GTP) gene expression. Annual Review of Biochemistry 66 581-611. (doi:10.1146/annurev.biochem.66.1.581)

He L, Sabet A, Djedjos S, Miller R, Sun X, Hussain MA, Radovick S \& Wondisford FE 2009 Metformin and insulin suppress hepatic gluconeogenesis through phosphorylation of CREB binding protein. Cell 137 635-646. (doi:10.1016/j.cell.2009.03.016)

Herberg FW, Maleszka A, Eide T, Vossebein L \& Tasken K 2000 Analysis of A-kinase anchoring protein (AKAP) interaction with protein kinase A (PKA) regulatory subunits: PKA isoform specificity in AKAP binding. Journal of Molecular Biology 298 329-339. (doi:10.1006/jmbi.2000.3662)

Herzig S, Long F, Jhala US, Hedrick S, Quinn R, Bauer A, Rudolph D, Schutz G, Yoon C, Puigserver P, et al. 2001 CREB regulates hepatic gluconeogenesis through the coactivator PGC-1. Nature $\mathbf{4 1 3}$ 179-183. (doi:10.1038/35093131)

Hinke SA, Navedo MF, Ulman A, Whiting JL, Nygren PJ, Tian G, Jimenez-Caliani AJ, Langeberg LK, Cirulli V, Tengholm A, et al. 2012 Anchored phosphatases modulate glucose homeostasis. EMBO Journal 31 3991-4004. (doi:10.1038/emboj.2012.244)

Ho D, Zhao X, Yan L, Yuan C, Zong H, Vatner DE, Pessin JE \& Vatner SF 2015 Adenylyl cyclase type 5 deficiency protects against diet-induced obesity and insulin resistance. Diabetes 64 2636-2645. (doi:10.2337/ db14-0494)

Howe DG, Wiley JC \& McKnight GS 2002 Molecular and behavioral effects of a null mutation in all PKA C beta isoforms. Molecular and Cellular Neurosciences 20 515-524. (doi:10.1006/mcne.2002.1119)

Hughes SD, Quaade C, Johnson JH, Ferber S \& Newgard CB 1993 Transfection of AtT-20ins cells with GLUT-2 but not GLUT-1 confers glucose-stimulated insulin secretion. Relationship to glucose metabolism. Journal of Biological Chemistry 268 15205-15212.

Hussain MA, Stratakis C \& Kirschner L 2012 Prkar1a in the regulation of insulin secretion. Hormone and Metabolic Research 44 759-765. (doi:10.1055/s-00000025)
Jarnaess E, Ruppelt A, Stokka AJ, Lygren B, Scott JD \& Tasken K 2008 Dual specificity A-kinase anchoring proteins (AKAPs) contain an additional binding region that enhances targeting of protein kinase A type I. Journal of Biological Chemistry 283 33708-33718. (doi:10.1074/jbc.M804807200)

Jensen J, Rustad PI, Kolnes AJ \& Lai YC 2011 The role of skeletal muscle glycogen breakdown for regulation of insulin sensitivity by exercise. Frontiers in Physiology 2 112. (doi:10.3389/fphys.2011.00112)

Johanns M, Lai YC, Hsu MF, Jacobs R, Vertommen D, Van Sande J, Dumont JE, Woods A, Carling D, Hue L, et al. 2016 AMPK antagonizes hepatic glucagon-stimulated cyclic AMP signalling via phosphorylationinduced activation of cyclic nucleotide phosphodiesterase 4B. Nature Communications 7 10856. (doi:10.1038/ncomms10856)

Josefsen K, Lee YC, Thams P, Efendic S \& Nielsen JH 2010 AKAP 18 alpha and gamma have opposing effects on insulin release in INS-1E cells. FEBS Letters 584 81-85. (doi:10.1016/j.febslet.2009.10.086)

Kaihara KA, Dickson LM, Jacobson DA, Tamarina N, Roe MW, Philipson LH \& Wicksteed B 2013 beta-Cell-specific protein kinase A activation enhances the efficiency of glucose control by increasing acute-phase insulin secretion. Diabetes 62 1527-1536. (doi:10.2337/ db12-1013)

Kaihara KA, Dickson LM, Ellenbroek JH, Orr CM, Layden BT \& Wicksteed B 2015 PKA enhances the acute insulin response leading to the restoration of glucose control. Diabetes $\mathbf{6 4} 1688-1697$. (doi:10.2337/db14-1051)

Ke B, Zhao Z, Ye X, Gao Z, Manganiello V, Wu B \& Ye J 2015 Inactivation of NF-kappaB p65 (RelA) in liver improved insulin sensitivity and inhibited cAMP/PKA pathway. Diabetes $\mathbf{6 4}$ 3355-3362. (doi:10.2337/db15-0242)

Kendall DM, Poitout V, Olson LK, Sorenson RL \& Robertson RP 1995 Somatostatin coordinately regulates glucagon gene expression and exocytosis in HIT-T15 cells. Journal of Clinical Investigation 96 2496-2502. (doi:10.1172/JCI118309)

Kim HB, Kim WH, Han KL, Park JH, Lee J, Yeo J \& Jung MH 2010 cAMPresponse element binding protein (CREB) positively regulates mouse adiponectin gene expression in 3T3-L1 adipocytes. Biochemical and Biophysical Research Communications 391 634-639. (doi:10.1016/j. bbrc.2009.11.111)

Kirschner LS, Carney JA, Pack SD, Taymans SE, Giatzakis C, Cho YS, Cho-Chung YS \& Stratakis CA 2000 Mutations of the gene encoding the protein kinase A type I-alpha regulatory subunit in patients with the Carney complex. Nature Genetics 26 89-92. (doi:10.1038/79238)

Kirschner LS, Yin Z, Jones GN \& Mahoney E 2009 Mouse models of altered protein kinase A signaling. Endocrine-Related Cancer 16 773-793. (doi:10.1677/ERC-09-0068)

Kitamura T, Kitamura Y, Kuroda S, Hino Y, Ando M, Kotani K, Konishi H, Matsuzaki H, Kikkawa U, Ogawa W, et al. 1999 Insulininduced phosphorylation and activation of cyclic nucleotide phosphodiesterase 3B by the serine-threonine kinase Akt. Molecular Cell Biology 19 6286-6296. (doi:10.1128/МСB.19.9.6286)

Knepel W, Chafitz J \& Habener JF 1990 Transcriptional activation of the rat glucagon gene by the cyclic AMP-responsive element in pancreatic islet cells. Molecular Cell Biology 10 6799-6804. (doi:10.1128/MCB.10.12.6799)

Knight JD \& Kothary R 2011 The myogenic kinome: protein kinases critical to mammalian skeletal myogenesis. Skeletal Muscle 129. (doi:10.1186/2044-5040-1-29)

Krebs EG \& Beavo JA 1979 Phosphorylation-dephosphorylation of enzymes. Annual Review of Biochemistry 48 923-959. (doi:10.1146/ annurev.bi.48.070179.004423)

Krintel C, Osmark P, Larsen MR, Resjo S, Logan DT \& Holm C 2008 Ser649 and Ser650 are the major determinants of protein kinase A-mediated activation of human hormone-sensitive lipase against lipid substrates. PLOS ONE 3 e3756. (doi:10.1371/journal. pone.0003756)

Published by Bioscientifica Ltd. 
Leahy P, Crawford DR, Grossman G, Gronostajski RM \& Hanson RW 1999 CREB binding protein coordinates the function of multiple transcription factors including nuclear factor I to regulate phosphoenolpyruvate carboxykinase (GTP) gene transcription. Journal of Biological Chemistry 274 8813-8822. (doi:10.1074/ jbc.274.13.8813)

Lee LC, Maurice DH \& Baillie GS 2013 Targeting protein-protein interactions within the cyclic AMP signaling system as a therapeutic strategy for cardiovascular disease. Future Medicinal Chemistry $\mathbf{5}$ 451-464. (doi:10.4155/fmc.12.216)

Leibiger B, Moede T, Muhandiramlage TP, Kaiser D, Vaca Sanchez P, Leibiger IB \& Berggren PO 2012 Glucagon regulates its own synthesis by autocrine signaling. PNAS 109 20925-20930. (doi:10.1073/ pnas.1212870110)

Lembo G, Capaldo B, Rendina V, Iaccarino G, Napoli R, Guida R, Trimarco B \& Sacca L 1994 Acute noradrenergic activation induces insulin resistance in human skeletal muscle. American Journal of Physiology 266 E242-E247.

Lester LB, Langeberg LK \& Scott JD 1997 Anchoring of protein kinase A facilitates hormone-mediated insulin secretion. PNAS 94 14942-14947. (doi:10.1073/pnas.94.26.14942)

Li YQ, Shrestha YB, Chen M, Chanturiya T, Gavrilova O \& Weinstein LS 2016 Gsalpha deficiency in adipose tissue improves glucose metabolism and insulin sensitivity without an effect on body weight. PNAS 113 446-451. (doi:10.1073/pnas.1517142113)

Liang H \& Ward WF 2006 PGC-1alpha: a key regulator of energy metabolism. American Journal of Physiology: Advances in Physiology Education 30 145-151. (doi:10.1152/advan.00052.2006)

Light PE, Manning Fox JE, Riedel MJ \& Wheeler MB 2002 Glucagon-like peptide- 1 inhibits pancreatic ATP-sensitive potassium channels via a protein kinase A- and ADP-dependent mechanism. Molecular Endocrinology 16 2135-2144. (doi:10.1210/me.2002-0084)

Lim JH, Gerhart-Hines Z, Dominy JE, Lee Y, Kim S, Tabata M, Xiang YK \& Puigserver P 2013 Oleic acid stimulates complete oxidation of fatty acids through protein kinase A-dependent activation of SIRT1PGC1alpha complex. Journal of Biological Chemistry 288 7117-7126. (doi:10.1074/jbc.M112.415729)

Liu X, Perusse F \& Bukowiecki LJ 1994 Chronic norepinephrine infusion stimulates glucose uptake in white and brown adipose tissues. American Journal of Physiology 266 R914-R920.

London E, Nesterova M, Sinaii N, Szarek E, Chanturiya T, Mastroyannis SA, Gavrilova O \& Stratakis CA 2014 Differentially regulated protein kinase $\mathrm{A}$ (PKA) activity in adipose tissue and liver is associated with resistance to diet-induced obesity and glucose intolerance in mice that lack PKA regulatory subunit type IIalpha. Endocrinology 155 3397-3408. (doi:10.1210/en.2014-1122)

Ma X, Zhang Y, Gromada J, Sewing S, Berggren PO, Buschard K, Salehi A, Vikman J, Rorsman P \& Eliasson L 2005 Glucagon stimulates exocytosis in mouse and rat pancreatic alpha-cells by binding to glucagon receptors. Molecular Endocrinology 19 198-212. (doi:10.1210/me.2004-0059)

Maeda T \& Horiuchi N 2009 Simvastatin suppresses leptin expression in 3T3-L1 adipocytes via activation of the cyclic AMP-PKA pathway induced by inhibition of protein prenylation. Journal of Biochemistry 145 771-781. (doi:10.1093/jb/mvp035)

Makaula S, Lochner A, Genade S, Sack MN, Awan MM \& Opie LH $2005 \mathrm{H}-89$, a non-specific inhibitor of protein kinase A, promotes post-ischemic cardiac contractile recovery and reduces infarct size. Journal of Cardiovascular Pharmacology 45 341-347. (doi:10.1097/01.fjc.0000156825.80951.14)

Mangmool S, Denkaew T, Phosri S, Pinthong D, Parichatikanond W, Shimauchi T \& Nishida M 2016 Sustained betaAR stimulation mediates cardiac insulin resistance in a PKA-dependent manner. Molecular Endocrinology 30 118-132. (doi:10.1210/me.2015-1201)

Mantovani G, Bondioni S, Alberti L, Gilardini L, Invitti C, Corbetta S, Zappa MA, Ferrero S, Lania AG, Bosari S, et al. 2009 Protein kinase A regulatory subunits in human adipose tissue: decreased R2B expression and activity in adipocytes from obese subjects. Diabetes 58 620-626. (doi:10.2337/db08-0585)

Means CK, Lygren B, Langeberg LK, Jain A, Dixon RE, Vega AL, Gold MG, Petrosyan S, Taylor SS, Murphy AN, et al. 2011 An entirely specific type I A-kinase anchoring protein that can sequester two molecules of protein kinase A at mitochondria. PNAS $\mathbf{1 0 8}$ E1227-E1235. (doi:10.1073/pnas.1107182108)

Mehrani H \& Storey KB 1993 Control of glycogenolysis and effects of exercise on phosphorylase kinase and cAMP-dependent protein kinase in rainbow trout organs. Biochemistry and Cell Biology $\mathbf{7 1}$ 501-506. (doi:10.1139/o93-072)

Mighiu PI, Yue JT, Filippi BM, Abraham MA, Chari M, Lam CK, Yang CS, Christian NR, Charron MJ \& Lam TK 2013 Hypothalamic glucagon signaling inhibits hepatic glucose production. Nature Medicine 19 766-772. (doi:10.1038/nm.3115)

Miller CP, Lin JC \& Habener JF 1993 Transcription of the rat glucagon gene by the cyclic AMP response element-binding protein CREB is modulated by adjacent CREB-associated proteins. Molecular and Cellular Biology 13 7080-7090. (doi:10.1128/MCB.13.11.7080)

Miller RA, Chu Q, Xie J, Foretz M, Viollet B \& Birnbaum MJ 2013 Biguanides suppress hepatic glucagon signalling by decreasing production of cyclic AMP. Nature 494 256-260. (doi:10.1038/ nature11808)

Miyoshi H, Perfield JW2nd, Souza SC, Shen WJ, Zhang HH, Stancheva ZS, Kraemer FB, Obin MS \& Greenberg AS 2007 Control of adipose triglyceride lipase action by serine 517 of perilipin A globally regulates protein kinase A-stimulated lipolysis in adipocytes. Journal of Biological Chemistry 282 996-1002. (doi:10.1074/jbc. M605770200)

Morton GJ \& Schwartz MW 2011 Leptin and the central nervous system control of glucose metabolism. Physiological Reviews 91 389-411. (doi:10.1152/physrev.00007.2010)

Murray AJ 2008 Pharmacological PKA inhibition: all may not be what it seems. Science Signaling 1 re4. (doi:10.1126/scisignal.122re4)

Newhall KJ, Cummings DE, Nolan MA \& McKnight GS 2005 Deletion of the RIIbeta-subunit of protein kinase A decreases body weight and increases energy expenditure in the obese, leptin-deficient ob/ob mouse. Molecular Endocrinology 19 982-991. (doi:10.1210/me.20040343)

Ngala RA, O'Dowd JF, Stocker CJ, Cawthorne MA \& Arch JR 2013 beta2adrenoceptor agonists can both stimulate and inhibit glucose uptake in mouse soleus muscle through ligand-directed signalling. NaunynSchmiedeberg's Archives of Pharmacology 386 761-773. (doi:10.1007/ s00210-013-0860-5)

Niswender CM, Willis BS, Wallen A, Sweet IR, Jetton TL, Thompson BR, Wu C, Lange AJ \& McKnight GS 2005 Cre recombinase-dependent expression of a constitutively active mutant allele of the catalytic subunit of protein kinase A. Genesis 43 109-119. (doi:10.1002/ gene.20159)

Nolan CJ, Damm P \& Prentki M 2011 Type 2 diabetes across generations: from pathophysiology to prevention and management. Lancet 378 169-181. (doi:10.1016/S0140-6736(11)60614-4)

Nolan MA, Sikorski MA \& McKnight GS 2004 The role of uncoupling protein 1 in the metabolism and adiposity of RII beta-protein kinase A-deficient mice. Molecular Endocrinology 18 2302-2311. (doi:10.1210/me.2004-0194)

Oddis CV, Simmons RL, Hattler BG \& Finkel MS 1996 Protein kinase A activation is required for IL-1-induced nitric oxide production by cardiac myocytes. American Journal of Physiology $\mathbf{2 7 1}$ C429-C434.

Ortmeyer HK 1997 Insulin decreases skeletal muscle cAMP-dependent protein kinase (PKA) activity in normal monkeys and increases PKA activity in insulin-resistant rhesus monkeys. Journal of Basic and Clinical Physiology and Pharmacology 8 223-235. (doi:10.1515/ JBCPP.1997.8.4.223) 
Otani T, Mizokami A, Hayashi Y, Gao J, Mori Y, Nakamura S, Takeuchi H \& Hirata M 2015 Signaling pathway for adiponectin expression in adipocytes by osteocalcin. Cellular Signalling 27 532-544. (doi:10.1016/j.cellsig.2014.12.018)

Pagnon J, Matzaris M, Stark R, Meex RC, Macaulay SL, Brown W, O'Brien PE, Tiganis T \& Watt MJ 2012 Identification and functional characterization of protein kinase A phosphorylation sites in the major lipolytic protein, adipose triglyceride lipase. Endocrinology 153 4278-4289. (doi:10.1210/en.2012-1127)

Park CR, Lewis SB \& Exton JH 1972 Relationship of some hepatic actions of insulin to the intracellular level of cyclic adenylate. Diabetes 21 439-446. (doi:10.2337/diab.21.2.S439)

Park SJ, Ahmad F, Philp A, Baar K, Williams T, Luo H, Ke H, Rehmann H Taussig R, Brown AL, et al. 2012 Resveratrol ameliorates aging-related metabolic phenotypes by inhibiting cAMP phosphodiesterases. Cell 148 421-433. (doi:10.1016/j.cell.2012.01.017)

Pernicova I \& Korbonits M 2014 Metformin--mode of action and clinical implications for diabetes and cancer. Nature Reviews. Endocrinology 10 143-156. (doi:10.1038/nrendo.2013.256)

Petyuk VA, Qian WJ, Hinault C, Gritsenko MA, Singhal M, Monroe ME, Camp DG 2nd, Kulkarni RN \& Smith RD 2008 Characterization of the mouse pancreatic islet proteome and comparative analysis with other mouse tissues. Journal of Proteome Research 7 3114-3126. (doi:10.1021/pr800205b)

Peverelli E, Ermetici F, Corbetta S, Gozzini E, Avagliano L, Zappa MA, Bulfamante G, Beck-Peccoz P, Spada A \& Mantovani G 2013 PKA regulatory subunit $\mathrm{R} 2 \mathrm{~B}$ is required for murine and human adipocyte differentiation. Endocrine Connections 2 196-207. (doi:10.1530/EC-130049)

Pidoux G \& Tasken K 2010 Specificity and spatial dynamics of protein kinase A signaling organized by A-kinase-anchoring proteins. Journal of Molecular Endocrinology 44 271-284. (doi:10.1677/JME10-0010)

Pidoux G, Witczak O, Jarnaess E, Myrvold L, Urlaub H, Stokka AJ, Kuntziger T \& Tasken K 2011 Optic atrophy 1 is an A-kinase anchoring protein on lipid droplets that mediates adrenergic control of lipolysis. EMBO Journal 30 4371-4386. (doi:10.1038/ emboj.2011.365)

Planas JV, Cummings DE, Idzerda RL \& McKnight GS 1999 Mutation of the RIIbeta subunit of protein kinase A differentially affects lipolysis but not gene induction in white adipose tissue. Journal of Biological Chemistry 274 36281-36287. (doi:10.1074/jbc.274.51.36281)

Proud CG, Rylatt DB, Yeaman SJ \& Cohen P 1977 Amino acid sequences at the two sites on glycogen synthetase phosphorylated by cyclic AMP-dependent protein kinase and their dephosphorylation by protein phosphatase-III. FEBS Letters 80 435-442. (doi:10.1016/ 0014-5793(77)80493-6)

Puigserver P, Rhee J, Donovan J, Walkey CJ, Yoon JC, Oriente F, Kitamura Y, Altomonte J, Dong H, Accili D, et al. 2003 Insulinregulated hepatic gluconeogenesis through FOXO1-PGC-1alpha interaction. Nature 423 550-555. (doi:10.1038/nature01667)

Quesada I, Tuduri E, Ripoll C \& Nadal A 2008 Physiology of the pancreatic alpha-cell and glucagon secretion: role in glucose homeostasis and diabetes. Journal of Endocrinology 199 5-19. (doi:10.1677/JOE-08-0290)

Quinn PG 1994 Inhibition by insulin of protein kinase A-induced transcription of the phosphoenolpyruvate carboxykinase gene. Mediation by the activation domain of cAMP response elementbinding protein (CREB) and factors bound to the TATA box. Journal of Biological Chemistry 269 14375-14378.

Reinton N, Haugen TB, Orstavik S, Skalhegg BS, Hansson V, Jahnsen T \& Tasken K 1998 The gene encoding the C gamma catalytic subunit of cAMP-dependent protein kinase is a transcribed retroposon. Genomics 49 290-297. (doi:10.1006/geno.1998.5240)

Rider MH, Bertrand L, Vertommen D, Michels PA, Rousseau GG \& Hue L 2004 6-phosphofructo-2-kinase/fructose-2,6-bisphosphatase: head-to-head with a bifunctional enzyme that controls glycolysis. Biochemical Journal 381 561-579. (doi:10.1042/BJ20040752)

Rojas JM \& Schwartz MW 2014 Control of hepatic glucose metabolism by islet and brain. Diabetes, Obesity \& Metabolism 16 33-40. (doi:10.1111/dom.12332)

Rosen ED \& Spiegelman BM 2006 Adipocytes as regulators of energy balance and glucose homeostasis. Nature 444 847-853. (doi:10.1038/ nature05483)

Rosenmund C, Carr DW, Bergeson SE, Nilaver G, Scott JD \& Westbrook GL 1994 Anchoring of protein kinase A is required for modulation of AMPA/kainate receptors on hippocampal neurons. Nature 368 853-856. (doi:10.1038/368853a0)

Sammons MF \& Lee EC 2015 Recent progress in the development of small-molecule glucagon receptor antagonists. Bioorganic \& Medicinal Chemistry Letters 25 4057-4064. (doi:10.1016/j.bmcl.2015.07.092)

Samuel VT, Beddow SA, Iwasaki T, Zhang XM, Chu X, Still CD, Gerhard GS \& Shulman GI 2009 Fasting hyperglycemia is not associated with increased expression of PEPCK or G6Pc in patients with Type 2 Diabetes. PNAS 106 12121-12126. (doi:10.1073/ pnas.0812547106)

Sapio L, Di Maiolo F, Illiano M, Esposito A, Chiosi E, Spina A \& Naviglio S 2014 Targeting protein kinase a in cancer therapy: an update. EXCLI Journal 13 843-855.

Sato M, Dehvari N, Oberg AI, Dallner OS, Sandstrom AL, Olsen JM, Csikasz RI, Summers RJ, Hutchinson DS \& Bengtsson T 2014 Improving type 2 diabetes through a distinct adrenergic signaling pathway involving mTORC2 that mediates glucose uptake in skeletal muscle. Diabetes 63 4115-4129. (doi:10.2337/db13-1860)

Scarlett JM \& Schwartz MW 2015 Gut-brain mechanisms controlling glucose homeostasis. F1000Prime Reports 7 12. (doi:10.12703/P7-12)

Schreyer SA, Cummings DE, McKnight GS \& LeBoeuf RC 2001 Mutation of the RIIbeta subunit of protein kinase A prevents diet-induced insulin resistance and dyslipidemia in mice. Diabetes 50 2555-2562. (doi:10.2337/diabetes.50.11.2555)

Schwartz MW, Seeley RJ, Tschop MH, Woods SC, Morton GJ, Myers MG \& D'Alessio D 2013 Cooperation between brain and islet in glucose homeostasis and diabetes. Nature 503 59-66. (doi:10.1038/nature12709)

Seino S \& Shibasaki T 2005 PKA-dependent and PKA-independent pathways for cAMP-regulated exocytosis. Physiological Reviews $\mathbf{8 5}$ 1303-1342. (doi:10.1152/physrev.00001.2005)

Sinnegger-Brauns MJ, Hetzenauer A, Huber IG, Renstrom E, Wietzorrek G, Berjukov S, Cavalli M, Walter D, Koschak A, Waldschutz R, et al. 2004 Isoform-specific regulation of mood behavior and pancreatic beta cell and cardiovascular function by L-type Ca 2+ channels. Journal of Clinical Investigation 113 1430-1439. (doi:10.1172/JCI20208)

Smith FD, Langeberg LK \& Scott JD 2006 The where's and when's of kinase anchoring. Trends in Biochemical Sciences 31 316-323. (doi:10.1016/j.tibs.2006.04.009)

Song WJ, Seshadri M, Ashraf U, Mdluli T, Mondal P, Keil M, Azevedo M, Kirschner LS, Stratakis CA \& Hussain MA 2011 Snapin mediates incretin action and augments glucose-dependent insulin secretion. Cell Metabolism 13 308-319. (doi:10.1016/j.cmet.2011.02.002)

Splawski I, Timothy KW, Sharpe LM, Decher N, Kumar P, Bloise R, Napolitano C, Schwartz PJ, Joseph RM, Condouris K, et al. 2004 $\mathrm{Ca}(\mathrm{V}) 1.2$ calcium channel dysfunction causes a multisystem disorder including arrhythmia and autism. Cell 119 19-31. (doi:10.1016/j. cell.2004.09.011)

Streeper RS, Hornbuckle LA, Svitek CA, Goldman JK, Oeser JK \& O'Brien RM 2001 Protein kinase A phosphorylates hepatocyte nuclear factor-6 and stimulates glucose-6-phosphatase catalytic subunit gene transcription. Journal of Biological Chemistry $27619111-$ 19118. (doi:10.1074/jbc.M101442200)

Stump CS, Henriksen EJ, Wei Y \& Sowers JR 2006 The metabolic syndrome: role of skeletal muscle metabolism. Annals of Medicine $\mathbf{3 8}$ 389-402. (doi:10.1080/07853890600888413)

Published by Bioscientifica Ltd. 
Sun Y, Liu S, Ferguson S, Wang L, Klepcyk P, Yun JS \& Friedman JE 2002 Phosphoenolpyruvate carboxykinase overexpression selectively attenuates insulin signaling and hepatic insulin sensitivity in transgenic mice. Journal of Biological Chemistry 277 23301-23307. (doi:10.1074/jbc.M200964200)

Szendroedi J, Schmid AI, Chmelik M, Krssak M, Nowotny P, Prikoszovich T, Kautzky-Willer A, Wolzt M, Waldhausl W \& Roden M 2011 Skeletal muscle phosphodiester content relates to body mass and glycemic control. PLOS ONE 6 e21846. (doi:10.1371/journal. pone.0021846)

Szkudelski T, Nowicka E \& Szkudelska K 2005 Leptin secretion and protein kinase A activity. Physiological Research 54 79-85.

Tasken K \& Aandahl EM 2004 Localized effects of cAMP mediated by distinct routes of protein kinase A. Physiological Reviews 84 137-167. (doi:10.1152/physrev.00021.2003)

Thiebaud D, Jacot E, DeFronzo RA, Maeder E, Jequier E \& Felber JP 1982 The effect of graded doses of insulin on total glucose uptake, glucose oxidation, and glucose storage in man. Diabetes 31 957-963. (doi:10.2337/diacare.31.11.957)

Thorens B, Deriaz N, Bosco D, DeVos A, Pipeleers D, Schuit F, Meda P \& Porret A 1996 Protein kinase A-dependent phosphorylation of GLUT2 in pancreatic beta cells. Journal of Biological Chemistry 271 8075-8081. (doi:10.1074/jbc.271.14.8075)

Torres VE \& Harris PC 2014 Strategies targeting cAMP signaling in the treatment of polycystic kidney disease. Journal of the American Society of Nephrology 25 18-32. (doi:10.1681/ASN.2013040398)

Tortora G, Caputo R, Damiano V, Bianco R, Pepe S, Bianco AR, Jiang Z, Agrawal S \& Ciardiello F 1997 Synergistic inhibition of human cancer cell growth by cytotoxic drugs and mixed backbone antisense oligonucleotide targeting protein kinase A. PNAS 94 12586-12591. (doi:10.1073/pnas.94.23.12586)

Tortora G \& Ciardiello F 2003 Antisense targeting protein kinase A type I as a drug for integrated strategies of cancer therapy. Annals of the New York Academy of Sciences 1002 236-243. (doi:10.1196/ annals.1281.026)

Troger J, Moutty MC, Skroblin P \& Klussmann E 2012 A-kinase anchoring proteins as potential drug targets. British Journal of Pharmacology 166 420-433. (doi:10.1111/j.1476-5381.2011.01796.x)

Turcotte LP \& Fisher JS 2008 Skeletal muscle insulin resistance: roles of fatty acid metabolism and exercise. Physical Therapy 88 1279-1296. (doi:10.2522/pti.20080018)

van Schaftingen E \& Gerin I 2002 The glucose-6-phosphatase system. Biochemical Journal 362 513-532. (doi:10.1042/bj3620513)

Vollert S, Kaessner N, Heuser A, Hanauer G, Dieckmann A, Knaack D, Kley HP, Beume R \& Weiss-Haljiti C 2012 The glucose-lowering effects of the PDE4 inhibitors roflumilast and roflumilast-N-oxide in db/db mice. Diabetologia 55 2779-2788. (doi:10.1007/s00125-0122632-z)

Wang Y, Li G, Goode J, Paz JC, Ouyang K, Screaton R, Fischer WH, Chen J, Tabas I \& Montminy M 2012 Inositol-1,4,5-trisphosphate receptor regulates hepatic gluconeogenesis in fasting and diabetes. Nature 485 128-132. (doi:10.1038/nature10988)

Weinstein LS 2014 Role of G(s)alpha in central regulation of energy and glucose metabolism. Hormone and Metabolic Research 46 841-844. (doi:10.1055/s-00000025)
Weiss S, Oz S, Benmocha A \& Dascal N 2013 Regulation of cardiac L-type $\mathrm{Ca}(2)(+)$ channel CaV1.2 via the beta-adrenergic-cAMPprotein kinase A pathway: old dogmas, advances, and new uncertainties. Circulation Research 113 617-631. (doi:10.1161/ CIRCRESAHA.113.301781)

Willis BS, Niswender CM, Su T, Amieux PS \& McKnight GS 2011 Celltype specific expression of a dominant negative PKA mutation in mice. PLOS ONE 6 e18772. (doi:10.1371/journal.pone.0018772)

Wouters EF, Bredenbroker D, Teichmann P, Brose M, Rabe KF, Fabbri LM \& Goke B 2012 Effect of the phosphodiesterase 4 inhibitor roflumilast on glucose metabolism in patients with treatment-naive, newly diagnosed type 2 diabetes mellitus. Journal of Clinical Endocrinology and Metabolism 97 E1720-E1725. (doi:10.1210/jc.2011-2886)

Wu B, Wei S, Petersen N, Ali Y, Wang X, Bacaj T, Rorsman P, Hong W, Sudhof TC \& Han W 2015 Synaptotagmin-7 phosphorylation mediates GLP-1-dependent potentiation of insulin secretion from beta-cells. PNAS 112 9996-10001. (doi:10.1073/pnas.1513004112)

Xie T, Chen M \& Weinstein LS 2010 Pancreas-specific Gsalpha deficiency has divergent effects on pancreatic alpha- and beta-cell proliferation. Journal of Endocrinology 206 261-269. (doi:10.1677/JOE-10-0030)

Xie T, Chen M, Zhang QH, Ma Z \& Weinstein LS 2007 Beta cell-specific deficiency of the stimulatory $G$ protein alpha-subunit Gsalpha leads to reduced beta cell mass and insulin-deficient diabetes. PNAS 104 19601-19606. (doi:10.1073/pnas.0704796104)

Yang SN \& Berggren PO 2006 The role of voltage-gated calcium channels in pancreatic beta-cell physiology and pathophysiology. Endocrine Reviews 27 621-676. (doi:10.1210/er.2005-0888)

Yang L \& McKnight GS 2015 Hypothalamic PKA regulates leptin sensitivity and adiposity. Nature Communations 6 8237. (doi:10.1038/ ncomms9237)

Yang J, Reshef L, Cassuto H, Aleman G \& Hanson RW 2009 Aspects of the control of phosphoenolpyruvate carboxykinase gene transcription. Journal of Biological Chemistry 284 27031-27035. (doi:10.1074/jbc.R109.040535)

Yehuda-Shnaidman E, Buehrer B, Pi J, Kumar N \& Collins S 2010 Acute stimulation of white adipocyte respiration by PKA-induced lipolysis. Diabetes 59 2474-2483. (doi:10.2337/db10-0245)

Zhang T, He J, Xu C, Zu L, Jiang H, Pu S, Guo X \& Xu G 2009 Mechanisms of metformin inhibiting lipolytic response to isoproterenol in primary rat adipocytes. Journal of Molecular Endocrinology 42 57-66. (doi:10.1677/JME-08-0130)

Zhao AZ 2005 Control of food intake through regulation of cAMP. Current Topics in Developmental Biology 67 207-224. (doi:10.1016/ S0070-2153(05)67006-8)

Zheng R, Yang L, Sikorski MA, Enns LC, Czyzyk TA, Ladiges WC \& McKnight GS 2013 Deficiency of the RIIbeta subunit of PKA affects locomotor activity and energy homeostasis in distinct neuronal populations. PNAS 110 E1631-E1640. (doi:10.1073/ pnas.1219542110)

Zisman A, Peroni OD, Abel ED, Michael MD, Mauvais-Jarvis F, Lowell BB, Wojtaszewski JF, Hirshman MF, Virkamaki A, Goodyear LJ, et al. 2000 Targeted disruption of the glucose transporter 4 selectively in muscle causes insulin resistance and glucose intolerance. Nature Medicine 6 924-928. (doi:10.1038/78693)

Received in final form 6 May 2016

Accepted 18 May 2016

Accepted Preprint published online 18 May 2016 http://jme.endocrinology-journals.org

DOI: 10.1530/JME-15-0316
() 2016 Society for Endocrinology Printed in Great Britain
Published by Bioscientifica Ltd. 